\title{
SKANDYNAWOWIE NAD RZEKĄ PARSĘTĄ: PROBLEM WIKIŃSKICH GROBÓW NA CMENTARZYSKU W ŚWIELUBIU NA POMORZU ZACHODNIM
}

\author{
SCANDINAVIANS ON THE BANKS OF THE PARSĘTA RIVER: \\ VIKING GRAVES IN THE CEMETERY AT \\ ŚWIELUBIE IN WESTERN POMERANIA
}

\begin{abstract}
Abstrakt: W pobliżu dziewiątowiecznego grodu w Bardach, na południe od Kołobrzegu, na Pomorzu Zachodnim, w miejscowości Świelubie, znajduje się cmentarzysko składające się z ponad stu kurhanów, spośród których zbadano trzydzieści sześć. W sześciu z nich, kobiecych i męskich, były przedmioty typowe dla Skandynawów. Znaleziska te przez długi czas stanowiły problem nie tylko badawczy, ale i polityczny. Artykuł jest poświęcony skandynawskim przedmiotom ze Świelubia, ich przynależności kulturowej i chronologii. Studium pozwoliło ustalić, że pochowani byli Szwedami, mającymi związek $\mathrm{z}$ handlowym emporium Birka na jeziorze Mälaren w środkowej Szwecji; datowanie grobów wskazuje na 2 poł. IX w.
\end{abstract}

Słowa kluczowe: osady, cmentarzyska, skandynawska kultura materialna, broń, ozdoby, Polska, Pomorze, Świelubie, Birka

\begin{abstract}
A cemetery of more than 100 barrows is located at Swielubie, near the $9^{\text {th }}$ c. stronghold of Bardy lying south of Kołobrzeg in Western Pomerania. In six of the 36 graves that were explored, containing both male and female burials, the grave goods consisted of typically Scandinavian objects. For a long time the discovery posed a problem that was also political in its nature. Author revisits the Scandinavian finds from Świelubie and discusses their cultural attribution and chronology. A close study of the artifacts identified the burials as of Swedes with ties to the trade emporium of Birka on Mälaren lake in central Sweden; the dating of the finds points to the $2^{\text {nd }}$ half of the $9^{\text {th }} \mathrm{c}$.
\end{abstract}

Keywords: settlements, cemeteries, Scandinavian material culture, weaponry, ornaments, Poland, Pomerania, Świelubie, Birka

${ }^{a}$ Dr hab. Władysław Duczko, prof. AFiBV, Akademia im. Aleksandra Gieysztora w Pułtusku, ul. Mickiewicza 36B, 06-100 Pułtusk, filia Akademii Finansów i Biznesu Vistula, Warszawa, wladyslawduczko@gmail.com, ORCID iD: https://orcid.org/0000-0001-9037-8944. 
Polskie Pomorze, część południowo-zachodniego wybrzeża Morza Bałtyckiego, zajmuje wyjątkową pozycję w archeologii Polski. To tutaj uformowała się tak ważna dla wczesnej epoki żelaza kultura pomorska, tu powstała kultura wielbarska należąca do skandynawskich grup, późniejszych Gotów, którzy po migracji na południe, a potem na zachód, odegrali wielką rolę $\mathrm{w}$ tworzeniu podstaw średniowiecznej Europy. To niedaleko od ujścia Wisły powstał we wczesnym średniowieczu słowiański Gdańsk. W epoce wikingów to jednak zachodnia część Pomorza była najgęściej zaludnioną i najbardziej gospodarczo rozwiniętą krainą wybrzeża i to tu, na jednej z wysp ujścia Odry, na Wolinie, istniał znaczący ośrodek handlowy, po którym pozostał bogaty materiał archeologiczny i legendy w sagach islandzkich.

We wczesnym średniowieczu Pomorze było tym obszarem Słowiańszczyzny Zachodniej, który znalazł się w obrębie handlowej aktywności Skandynawów tworzących w początkach epoki wikingów sieć osad na terenach władztw Obodrytów i Wieletów. To tam powstawały już w VIII w. duńskie emporia, centra rzemieślniczo-handlowe, których pozostałości odkryto w Groß Strömkendorf, Rostock-Dierkow, Ralsvik na Rugii, i w Menzlinie nad rzeką Pianą (Jöns 2009; Kleingärtner 2014). Z tych miejsc pochodzi bogaty i charakterystyczny materiał archeologiczny świadczący dobitnie o skali zaangażowania ludzi Północy w słowiański świat wybrzeża Morza Bałtyckiego. Menzlin był najdalej na wschód wysuniętym emporium, ale już po drugiej stronie Zalewu Szczecińskiego, na wspomnianej wyspie Wolin, nadal na obszarze wieleckim, powstał ośrodek typu emporium charakteryzujący się cechami szczególnymi - to sławny Wolin na brzegu rzeki Dziwny. Ośrodek ten stworzyli Słowianie, którzy od połowy $\mathrm{X}$ w. weszli w bliską symbiozę z Duńczykami zaangażowanymi w intensywny handel towarami z Północy (Stanisławski 2013). W 2 poł. X w. istniał tu także duński punkt militarny będący pod kontrolą Haralda Sinozębego nie typu Trelleborg! - jeden z takich, jakie król zakładał w różnych miejscach poza Danią (Duczko 1995; Słupecki 2000). Ponieważ do tej pory nie udało się stwierdzić w Wolinie obecności kobiet skandynawskich - brak charakterystycznych ozdób należałoby uznać to za cechę szczególną pokazującą, że ośrodek nad Dziwną nie był emporium tego rodzaju, jaki reprezentują duńskie emporia na wybrzeżu zachodniosłowiańskim. Tam bowiem można stwierdzić obecność skandynawskich rodzin tworzących małe społeczności o własnej tożsamości.

W obrębie Pomorza Zachodniego jest kilka miejsc, gdzie znaleziono skandynawskie przedmioty, czy nawet groby, ale tylko na cmentarzysku w Świelubiu, na południe od Kołobrzegu, nad dolną Parsętą, stwierdzono obecność pochówków Skandynawów, mężczyzn i kobiet, żyjących tu we wczesnej epoce wikingów. Odkryć dokonywano od końca XIX w., kiedy teren ten zaczęli penetrować badacze niemieccy, dla których skandynawskie znaleziska w tej części Europy były dowodem na znaczącą rolę, jaką Germanie odgrywali w miejscowych społecznościach słowiańskich. W dwudziestoleciu międzywojennym niektórzy historycy niemieccy wysunęli tezę o normańskim pochodzeniu Mieszka I, co wywołało kontrreakcję ze strony polskich badaczy, przede wszystkim Józefa Kostrzewskiego (Wierzbicki 2016). Po 1945 r. historyków i archeologów postawiono przed wymaganiami polityki historycznej mającej za cel podkreślanie słowiańskości tej nadmorskiej krainy i jej daw- 
Polish Pomerania, which is part of the southwestern Baltic coast, holds an exceptional position in Polish archaeology. It is the birthplace of Pomeranian Culture, which is of such importance for the early Iron Age, and of Wielbark Culture, which belongs to the Scandinavian groups, the later Goths, who migrated first south and then west to play an important role in laying the foundations for medieval Europe. It is here, not far from the mouth of the Vistula, that the early medieval Slavic Gdańsk was established. In Viking times, however, western Pomerania was the most densely inhabited and economically developed coastal region and it was here, on Wolin island at the mouth of the Oder river, that a successful trading center existed. Testifying to the role it played at the time is a rich archaeological record and legends passed on in Icelandic sagas.

In the early medieval period Scandinavians turned an eye toward Pomerania, the one part of Western Slavdom where they expanded their commercial activities, building at the dawn of the Viking Age a network of settlements in the tribal lands of the Obodrites and Veleti. Danish emporia were established there already in the $8^{\text {th }}$ c.; remains of such crafting and trading centers have been discovered at Groß Strömkendorf, Rostock-Dierkow, Ralswiek on Rügen and Menzlin on the Peene river (Jöns 2009; Kleingärtner 2014). The rich and characteristic archaeological material from these sites testifies to the scale of interest of people from the North in the Slavic world they knew existed along the Baltic coast. Menzlin was the easternmost of these emporia, but on the opposite side of Szczecin Bay, on the said island of Wolin, already in Veleti territory, a center emerged that had all the characteristics of an emporium with added unique features. The famous Wolin on the Dziwna river was established by Slavs who by the mid- $10^{\text {th }} \mathrm{c}$. were in a close symbiosis with the Danes trading intensively in goods from the North (Stanisławski 2013). From the $2^{\text {nd }}$ half of the $10^{\text {th }} \mathrm{c}$. there was also a Danish military post, not of the Trelleborg type, but of the kind that Harald "Bluetooth" Gormsson established in different places outside his kingdom (Duczko 1995; Słupecki 2000). The absence of Scandinavian women (typical ornaments suggestive of female presence have yet to be found) from Wolin should be taken as a specific trait indicating that the emporium on the Dziwna river did not resemble the Danish emporia on the western Slavic seashore. The latter are known to have included whole Scandinavian families which formed small communities cultivating their separate identity.

Scandinavian artifacts and even graves have been found at a few sites in Western Pomerania, but Świelubie south of Kołobrzeg, in the lower run of the Parsęta river, is the only cemetery with confirmed burials of Scandinavians, men and women, living here in the early Viking Age. The first discoveries date to the end of the $19^{\text {th }} \mathrm{c}$., when German scholars started to penetrate this region. For them Scandinavian finds in this part of Europe constituted proof of the role played by the Germanic tribes in the lives of Slavic communities inhabiting these territories. In the 1920s and 1930s, some German historians even argued in favor of the Norman origins of Mieszko I, triggering a counterreaction by Polish scholars with Józef Kostrzewski in the lead (Wierzbicki 2016). After 1945 historians and archaeologists had to deal with the demands of a historical policy aimed at emphasizing Slavdom in 
nych związków z Polską. Archeologom przypadła rola najważniejsza, gdyż tylko oni mogli dostarczyć bezpośrednich źródeł do wczesnych dziejów, czego historycy ze swojej strony dokonać nie mogli. Prowadzone przez kilkadziesiąt lat wykopaliska na Pomorzu znacznie wzbogaciły naszą wiedzę. W efekcie stworzono nowy obraz kultur tu istniejących. Wśród tych kultur, zwłaszcza z okresu wpływów rzymskich i wędrówek ludów, były takie, które i archeologicznie, i historycznie mogły być identyfikowane tylko $\mathrm{z}$ ludami germańskimi. Zmuszało to badaczy do zajęcia stanowiska, które byłoby politycznie poprawne, a jednocześnie akceptowalne dla nich naukowo. Trzeba przyznać, że zwyciężała tu rzetelność naukowa. Epoka wikingów była dla badaczy trudniejszym problemem, wiązała się bowiem ze studiami nad procesem powstawania państwa piastowskiego i każdy materialny ślad po wikingach był przyjmowany z niepokojem. Pamiętano o „kontrowersji normanistycznej", istniejącej w nauce europejskiej od XVIII w., ale także powszechnym wśród polskich historyków XIX i początku XX w. uznawaniu Skandynawów za twórców państwa polskiego (Wierzbicki 2011; 2019; Duczko 2017). Pokolenie historyków, takich jak Gerard Labuda, Henryk Łowmiański, czy archeologów, jak Jan Żak, Lech Leciejewicz, Władysław Łosiński składało się z badaczy zajmujących się wczesnymi dziejami i archeologią Skandynawii i publikujących materiały źródłowe i syntezy. Przez dłuższy czas „anty-normańskie” podejście Henryka Łowmiańskiego (zob. Łowmiański 1957) było podzielane przez większość badaczy w sposób mniej lub bardziej ostry. Wśród nich poznański archeolog Jan Żak wykazywał się szczególnie silną postawą krytyczną. Starannie studiując archeologiczną literaturę skandynawską i prowadząc kwerendy muzealne w Skandynawii, wykonał wielką pracę, publikując zidentyfikowane przez siebie skandynawskie przedmioty znalezione w Polsce (Żak 1963; 1967a; 1967b). Wartość zachował wszakże tylko katalog, natomiast wniosek sformułowany w tomie analitycznym, natrętnie później propagowany, o nieobecności Skandynawów na obszarze władztwa piastowskiego, ma zdecydowanie anachroniczny charakter.

Podjęcie badań archeologicznych nad dolną Parsętą w latach pięćdziesiątych XX w. i odkrycie tam skandynawskich przedmiotów zaktualizowało stare dyskusje nad rolą, jaką odgrywali ludzie z Północy działający w środowiskach słowiańskich. Zwiększenie się liczby skandynawskich zabytków w kontekście skandynawskiego obrządku pogrzebowego zmusiło badaczy do zajęcia stanowiska $\mathrm{w}$ „kwestii normańskiej". Ponieważ jednoznacznie skandynawski charakter odkrytego materiału archeologicznego nie pozwalał na inną kulturową atrybucję, archeolodzy rozumiejący delikatność polityczną sytuacji musieli wypowiadać się dyplomatycznie, co dla najbardziej zainteresowanych nie było specjalnym problemem wobec ich autentycznego anty-normańskiego podejścia. Ciekawe, że było to szczególnie widoczne u dwóch badaczy najlepiej orientujących się w archeologii wikińskiej, Jana Żaka i Lecha Leciejewicza, z których pierwszy starał się tłumaczyć obecność przedmiotów pochodzenia skandynawskiego jako rezultat działalności handlowej, natomiast drugi próbował zmniejszyć liczbę obcych pochówków do minimum, na przykład w przypadku Świelubia do jednego, dodając, że nie ma tu żadnych śladów świadczących o uzależnieniu miejscowej słowiańskiej ludności od Skandynawów 
Pomerania and its ancient ties with Poland. The most important input came from archaeologists, who, unlike the historians, could supply direct evidence for the early periods. A few dozen years of excavation projects in Pomerania contributed a significant body of data and, in effect, a new view of the cultures living in this region emerged. Some of these cultures, especially those from the age of Roman Influence and the Migration Period, could be identified archaeologically and historically only with the Germanic tribes. This imposed on researchers the need to develop views that would be at once politically correct and scientifically acceptable to them. Admittedly, scientific credibility won the day in this case. The Viking Age was a bigger issue, because it was strongly tied to the study of an emerging Piast dynasty statehood and every new instance of a material Viking presence raised anxiety. The "Norman controversy", present in European science from the $18^{\text {th }} \mathrm{c}$., but also shared by several Polish historians from the $19^{\text {th }}$ and early $20^{\text {th }} \mathrm{C}$., was never far from people's minds, accepting as it did the idea of the Scandinavians being the true founders of the Polish state (Wierzbicki 2011; 2019; Duczko 2017). A generation of historians of the likes of Gerard Labuda and Henryk Łowmiański, and archaeologists, including Jan Żak, Lech Leciejewicz, and Władysław Łosiński, researched the early history and archaeology of Scandinavia and published source material and syntheses. For a long time, Łowmiański's "anti-Norman" approach (cf. Łowmiański 1957) was largely shared by most researchers. Żak, an archaeologist from Poznań, was perhaps the most ardent follower of this view, having studied thoroughly the Scandinavian archaeological literature on the subject and gone on a quest through museums in Scandinavia. He was able to identify Scandinavian artifacts among the finds from Poland, and crowned this great task with a series of publications (Żak 1963; 1967a; 1967b). The catalog has retained its cognitive value, but not the conclusions presented in the analytical volume, later obsessively propagated, about the absence of Scandinavians from the Piast realm. These view are definitely an anachronism today.

Archaeological excavations in the lower run of the Parsęta river in the 1950s and the discovery of Scandinavian artifacts there activated the old discussion about the role played by people from the North in a Slavic environment. Faced with new finds related to Scandinavian burial rites, researchers were challenged to take up the "Norman" issue. The univocally Scandinavian character of the archaeological material did not support a different cultural attribution, hence the highly diplomatic approach of archaeologists aware of the political repercussions of these discoveries, an attitude that the most interested parties did not find difficult to maintain in view of their authentic anti-Norman convictions. Interestingly, among the ones presenting this attitude in the most conspicuous fashion were two of the best experts in Viking archaeology. Żak attempted to explain the presence of artifacts of Scandinavian origin as proof of a trade exchange, while Leciejewicz cut down on the number of confirmed foreign burials, reducing the number of such graves from Swielubie to just one and declaring the absence of any evidence whatsoever for the local Slavic peoples being dependent on the Scandinavians (Leciejewicz 1993, p. 53). Łosiński, who excavated Bardy-Świelubie, also started out by limiting the foreigners to just 
(Leciejewicz 1993, s. 53). Władysław Łosiński, prowadząc wykopaliska w Bardach-Świelubiu, też na początku uznawał obecność tylko „pojedynczych obcych przybyszów" (Łosiński 1972, s. 251) i dopiero z czasem zaakceptował tam większą grupę Skandynawów, zresztą nie nadając temu faktowi szczególnego znaczenia. Z jednej strony było to słuszne, ale $\mathrm{z}$ drugiej prowadziło do zatarcia rozmiaru roli, jaką Skandynawowie odgrywali w obrębie basenu Morza Bałtyckiego.

Sprawa obecności wikińskiej na ziemiach polskich była kłopotliwa dla badaczy przez cały okres zależności politycznej Polski od Związku Sowieckiego i trzeba było jego upadku, aby mogło zacząć się pojawiać inne podejście do problemu. Nie było to łatwe dla starszej generacji, natomiast młodsi archeolodzy, dzięki coraz częstszym wyjazdom zagranicznym, mieli możliwość nabycia innego, „niepolitycznego”, spojrzenia. Przyczyniło się też do tego szerokie, globalne, zainteresowanie wikingami, które spowodowało podchodzenie do skandynawskich znalezisk z otwartością i fascynacją, często większą niż posiadana wiedza o wikińskiej archeologii.

Będąc archeologiem nie tylko szwedzkim, ale i polskim, brałem udział w badaniach nad charakterem obecności skandynawskiej w epoce wikingów na terenie obecnej Polski. Ich wyniki przedstawiłem w kilku artykułach (Duczko 2000; 2011; 2014; 2016a; 2016b; 2016c; 2016d; 2017). Oprócz wskazania słowiańskiego charakteru Wolina i jego wyjątkowej pozycji jako ważnego ośrodka handlu i rzemiosła, z silnym wkładem duńskim, podkreśliłem znaczenie ośrodka osadniczego w Bardach-Świelubiu, gdzie kilka grobów ze skandynawskim wyposażeniem uznałem za szwedzkie. Ponieważ ta identyfikacja nie była podbudowana dokładniejszą analizą, chciałbym ją przeprowadzić w niniejszym artykule.

\section{KOMPLEKS OSADNICZY BARDY-ŚWIELUBIE}

Jednym z najostrzej dyskutowanych tematów w archeologii polskiej nie jest „kwestia normańska”, ale sprawa pochodzenia Słowian. Nieustające spory między zwolennikami autochtonizmu tego ludu na obszarze między Odrą a Wisłą i ich oponentami twierdzącymi, że był on przybyszem ze wschodu, nadal nie są zakończone. Nie będziemy się tym zajmować, wystarczy stwierdzić, że polscy badacze wczesnośredniowiecznego Pomorza, mimo iż byli autochtonistami, uznawali populację zajmującą tę część wybrzeża Bałtyku za przybyszy - bez ustalenia, skąd - w V, ewentualnie w VI w. Badania „odmładzające” chronologię ceramiki wymusiły przesunięcie pojawienia się Słowian na następne stulecie, a pełną stabilizację osadnictwa na VIII w. (Łosiński 2008, s. 71). Obszar od ujścia rzeki Parsęty do jej dolnego biegu został poddany szczególnie intensywnym badaniom archeologicznym, które pokazały jego gęste zasiedlenie i rozwój gospodarczy mający związek z istnieniem salin kołobrzeskich (Dulinicz 2001, s. 190 nn., ryc. 203). Na terenach dolno- i środkowoparsęckich powstały w IX w. liczne duże grody, określane przez archeologów jako typ Feldberg. Jednym z nich był dwuczłonowy gród w Bardach, stanowisko nr 1 (ryc. 1). Gród ten, zbadany przez Władysława Łosińskiego, został przez niego uznany najpierw za jeden z wielu ośrodków władzy lokalnego plemienia, potem za główne centrum 


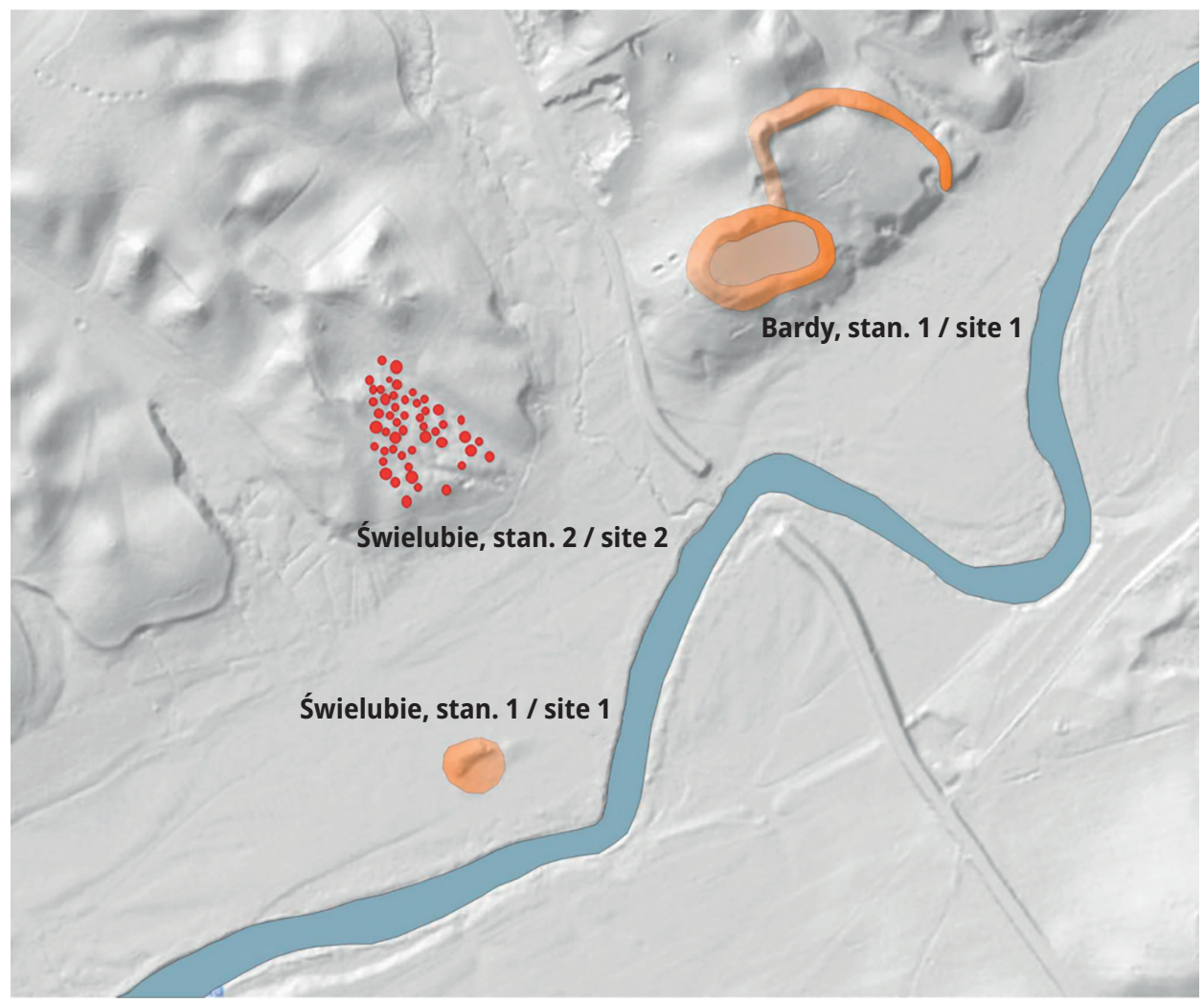

Ryc. 1. Pomorze, dolna Parsęta

Bardy - grodzisko, stan. 1; Świelubie - gródek, stan. 1; Świelubie - cmentarzysko, stan. 2.

Opracowała K. Skrzyńska

Fig. 1. Pomerania, lower Parsęta river valley

Bardy - stronghold, site 1; Świelubie - stronghold, site 1; Świelubie - cemetery, site 2.

Processing K. Skrzyńska

a few individuals (Łosiński 1972, p. 251) and only with time accepted the idea of the presence of a larger group of Scandinavians without attaching much importance to the fact. This was true on one hand, but on the other, it led to an effacement of the role played by the Scandinavians in the Baltic region.

Viking presence in Polish territories remained an awkward issue for Polish researchers as long as Poland was politically dependent on the Soviet Union and an entire political world system had to collapse before a different approach could develop. It was not easy for members of the older generation, but the younger archaeologists benefited from increasingly frequent travel abroad to foster a different "apolitical" view of matters. A global interest in Vikings was also instrumental in generating a fascination with all things Scandinavian that was often incommensurate to a given individual's knowledge of Viking archaeology. 
tego plemienia będące także centrum gospodarczym. Ta ostatnia funkcja miała być powodem pojawienia się tutaj grupy Skandynawów, „...w skład której wchodzili głównie rzemieślnicy i kupcy wraz z rodzinami, którzy chowali swych zmarłych na założonym przez siebie cmentarzu w Świelubiu, z czasem będącym również miejscem spoczynku słowiańskich członków społeczności” (Łosiński 2008, s. 85-86).

Bardzkie centrum funkcjonowało do przełomu IX i X w., kiedy na skutek zachodzących przemian w strukturach społecznych manifestujących się tworzeniem elit straciło swoje znaczenie. Archeologicznie jest to potwierdzone powstawaniem małych silnie ufortyfikowanych grodów typu Tornow. Taki właśnie gród został zbudowany w dolinie Parsęty (Świelubie, stanowisko nr 1, patrz ryc. 1), poniżej wysoczyzny, na której znajdowało się cmentarzysko świelubskie (Świelubie, stanowisko nr 2; patrz ryc. 1); miała tutaj być siedziba wielmoży panującego nad najbliższym terytorium (Łosiński 2008, s. 77, 162 nn.). Zmiany powodujące upadek wielkiego grodu w Bardach miały również spowodować odejście Skandynawów. Czy rzeczywiście byli oni do tego stopnia strukturalnie związani z istnieniem ośrodka bardzkiego, że z chwilą jego upadku podjęli decyzję, albo zostali do niej zmuszeni, opuszczenia terenu dolnej Parsęty bez próby wejścia we współpracę z nowopowstałą elitą? Co o tym mogą powiedzieć przedmioty znalezione $\mathrm{w}$ świelubskich pochówkach? Zróbmy ich przegląd, przypominając, że skandynawskie artefakty są, oprócz dirhemów, jedynymi zabytkami, które dają nam możliwość ustalenia czasu pobytu grupy z Północy.

\section{CMENTARZYSKO W ŚWIELUBIU}

Niemieckie badania w przedwojennym Zwilipp nie były ani systematyczne, ani zaawansowane. Podczas amatorskich wykopalisk w roku 1897 zbadany został zbudowany z kamieni kopiec I, w którym znaleziono takie przedmioty, jak owalna zapinka, dwa szklane paciorki, bursztyn, igielnik z brązu, trzy pionki do gry i fragmenty glinianych naczyń. Był to jedyny grób zawierający przedmioty, w następnych kopcach: nry II i III przekopanych w 1900 r. oraz IV, V i VI - w 1923 r., nie odkryto nic podobnego (Eggers 1938).

Powojenne wykopaliska były prowadzone w latach 1962-1971 przez Władysława Łosińskiego. Zbadano wówczas 30 grobów pod kopcami, gdzie - z wyjątkiem kilku grobów szkieletowych - dominowały pochówki ciałopalne (Łosiński 1972, tabela XV, s. 260-270). Informacje o cmentarzysku - o nadanej mu nazwie stanowisko 2 - znajdują się w większych lub mniejszych publikacjach, całość nie została dotychczas opublikowana w formie monograficznej (Łosiński 1964; 1966; 1968; $1969 ; 1972 ; 1973,1974 ; 1979 ; 1993 ; 1998 ; 2000 ; 2003 ; 2008)$.

Stan zachowania cmentarzyska został przedstawiony jako niedobry: „Ze względu na różnego rodzaju prace ziemne prowadzone na terenie cmentarzyska, większość kopców uległa daleko idącej niwelacji, a niekiedy całkowitej zagładzie. Podanie pierwotnej rzeczywistej liczby kurhanów nie jest zatem możliwe. Niektóre, w terenie niewidoczne, ujawniły dopiero prace wykopaliskowe" (Łosiński 2008, s. 163, przypis 30). W. Łosiński tak pisał dalej o tym stanowisku: „Na cmentarzysku skła- 
Being both a Polish and Swedish archaeologist, the present author participated in research on Scandinavian presence in the territories of modern Poland during the Viking Age and has published the results of his studies (Duczko 2000; 2011; 2014; 2016a; 2016b; 2016c; 2016d; 2017). In these publications, the author has demonstrated the Slavic character of Wolin and the exceptional role of this settlement as an important trade and crafts center with extensive Danish input. The importance of the settlement at Bardy-Świelubie was emphasized as well, a few of the graves with Scandinavian artifacts being attributed to the Swedish. The attributions lacked solid support in an extended analysis, hence the present article filling the gap.

\section{THE SETTLEMENT COMPLEX IN BARDY-ŚWIELUBIE}

The question of the origins of the Slavs rather than the "Norman issue" is at the core of the most heated debate in Polish archaeology. The incessant argument between proponents of the autochthonous character of the people inhabiting the territories between the Oder and the Vistula and those who would have them come from the east does not seem to have an end in sight. Without going deeper into the question, suffice it to say that Polish scholars studying early medieval Pomerania belonged to the autochthonous school and yet they assumed that the population of this part of the Baltic coast was not native to it and had come there - from an unknown place - sometime in the $5^{\text {th }}$, perhaps $6^{\text {th }} \mathrm{c}$. Research into ceramic chronology, assigning a younger date to the pottery than previously assumed, resulted in pushing the coming of the Slavs down by a century and dating their full stabilization in the new territories to the $8^{\text {th }}$ c. (Losiński 2008, p. 71). Intensive archaeological research at the mouth and in the lower run of the Parsęta river revealed dense settlement and economic development centered on the Kołobrzeg salines (Dulinicz 2001, p. 190ff., Fig. 203). A series of large strongholds of the Feldberg type, as it is referred to in archaeological nomenclature, took root in the region of the lower and middle run of the river. The double-segment stronghold at Bardy site 1 was one of them (Fig. 1). Łosiński, who excavated it, considered it at first as one of the many local tribal power centers, then as the main quarters of this tribe and at the same time also an economic center sufficiently attractive to bring in a group of Scandinavians, "... made up chiefly of craftsmen and traders with their families, who buried their dead in a burial ground that they established at Świelubie, which became over time a place of burial also for members of the Slavic community" (Łosiński 2008, pp. 85-86).

Bardy functioned through the end of the $9^{\text {th }} \mathrm{c}$., losing importance in the beginning of the $10^{\text {th }} \mathrm{c}$. as a result of social transformation manifested in the formation of elites. The archaeological manifestation of this are small, heavily fortified strongholds of the Tornow type and one such stronghold was built at this time in the valley of the Parsęta (Świelubie, site 1, cf. Fig. 1), at the base of the high ground where the Świelubie cemetery was located (Świelubie, site 2; cf. Fig. 1). The stronghold was 
dającym się co najmniej ze stu kurhanów, rozmieszczonych w dwóch grupach, metodami wykopaliskowymi, nie licząc starszych rozkopywań sprzed drugiej wojny światowej, rozpoznano blisko 1/3 mogił, w większości w zwartym bloku wykopów. Okazało się, że zwyczajem pogrzebowym wyraźnie dominującym było ciałopalenie. Odkryto zaledwie 4 pochówki szkieletowe, znajdujące się albo bezpośrednio u podnóża kopców, albo w obrębie przestrzeni międzykurhanowej. W kurhanach w przewadze o założeniu kolistym, pomijając kopce "puste" należące do grupy cenotafów, zalegały wyłącznie pochówki ciałopalne, głównie typu podnasypowego. Zarówno forma grobu, jak i rodzaj pochówku mieszczą się w tradycji pogrzebowej charakterystycznej dla skandynawskiego kręgu kulturowego [...]. Za skandynawskim pochodzeniem zmarłych pochowanych w kolistych kopcach na cmentarzysku w Świelubiu przemawia nie tylko forma pochowków, ale i rodzaj i sposób wyposażania zmarłych. Są to wszystko istotne cechy diagnostyczne umożliwiające identyfikację etniczną zmarłych" (Łosiński 2008, s. 163).

Z czasem Łosiński uznał, że cmentarzysko świelubskie było nie tylko miejscem pochówków skandynawskich, twierdząc, że: „Nieuprawniony jest ponadto pogląd, jakoby na cmentarzysku spoczywali wyłącznie Skandynawowie. Stwierdzono, że w Świelubiu nakładają się na siebie trzy niezależne tradycje pogrzebowe [...]. Zdecydowaną większość grobów kurhanowych wiązać można z tradycją skandynawską. Jeden kurhan w sposób dość istotny nie mieści się jednak w tym kanonie. Była to mogiła z pochówkiem ciałopalnym złożonym na szczycie kurhanu, który otaczał rów o założeniu czworobocznym. Wzniesienie tego kopca było, jak sądzę, pochodną impulsów przenikających na wybrzeża Bałtyku z południowej prowincji rozsiedlenia Słowian Zachodnich [...]. Później ta idea szeroko rozprzestrzeniła się w północnej części naszego kraju i na północnym Połabiu [...]. W Świelubiu odkryto ponadto głównie w obrębie przestrzeni międzykurhanowej, ale również u podnóża kopców, groby jamowe dużych rozmiarów z pochówkami ciałopalnymi, niekiedy również ze śladami inhumacji o cechach typowych dla grobów typu Alt Käbelich [...]. Wydaje się, że tę formę grobu można uznać za charakterystyczną dla tej grupy Słowian, która zamieszkiwała obszary dawniej zaliczane do tzw. bezpochówkowej strefy sepulkralnej [...]. Cmentarzysko w Świelubiu byłoby zatem nie tylko miejscem pochówku skandynawskich przybyszów, ale i słowiańskich mieszkańców bardzko-świelubskiej wspólnoty terytorialnej [...]. Tu składano szczątki jedynie tych obywateli grodu i osad podgrodowych w Bardach, których za życia łączyły bliższe kontakty z przybyszami z Północy. Powstawanie tego typu relacji międzyludzkich prowadziło zapewne do stopniowej akulturacji przybyszów [...]. W każdym razie z X stulecia brak danych, które świadczyłyby o przetrwaniu w tym czasie w rejonie dolnej Parsęty liczniejszej grupy potomków dawnej skandynawskiej społeczności” (Łosiński 2008, s. 165).

Badacz Świelubia doszedł do wniosku, że z cmentarzyska, o którym sądził, że było wykorzystywane tylko przez Skandynawów, w rzeczywistości korzystali także niektórzy przedstawiciele miejscowych grup społecznych. Jeżeli chodzi o struktury jamowe typu Alt Käbelich, to były one pozostałościami po bliżej nieznanych rytuałach funeralnych, nieprowadzących do pochówku. Ten rodzaj funeralnych pozostałości jest najczęściej spotykany na obszarach zajmowanych przez plemiona 
supposed to be the residence of the lord of the neighboring land (Łosiński 2008, p. 77, 162ff.). The changes that led to the fall of the great Bardy stronghold also resulted in the departure of the Scandinavians. Were they structurally so deeply integrated into the Bardy center that they made the decision to leave when it fell? or were they forced to leave the valley of the Parsęta river without even making an effort to negotiate coexistence with a rising new elite? Can the artifacts from the graves in Swielubie tell the story to any degree? The following is a review of these artifacts, keeping in mind that they are, beside the dirhams, the only dating evidence for the presence of this group from the North in Western Pomerania.

\section{THE CEMETERY IN ŚWIELUBIE}

German investigations in prewar Zwilipp were neither regular nor advanced. Amateur digging in 1897 uncovered a stone mound (I), which yielded in effect an oval brooch, two glass beads, a piece of amber, a bronze needle case, three game counters and sherds from a clay pots. Mounds II and III, which were explored in 1900 , and IV, V and VI, excavated in 1923, did not produce any finds of the kind (Eggers 1938).

After the second world war in the years 1962-1971, Łosiński explored 30 graves with barrow superstructures, the bulk of them turning out to be cremations except of very few inhumations graves (Łosiński 1972, Table XV, pp. 260-270). Information about the cemetery - referred to as site 2 - can be found in many publications great and small, but the entirety of the finds has yet to be published in monograph form (Łosiński 1964; 1966; 1968; 1969; 1972; 1973, 1974; 1979; 1993; 1998; 2000; 2003; 2008).

The cemetery was poorly preserved to judge by the excavator's description: "Earthworks of various kinds in the cemetery area have led to most of the mounds being more or less leveled and even completely destroyed. Hence, a precise count of the barrows is not possible. Some which are invisible on the ground were revealed only as a result of excavation work" (Łosiński 2008, p. 163, note 30). Łosiński wrote: "The cemetery composed of at least 100 barrows, arranged in two groups, was investigated at least in a third of this number (with the exception of prewar digging), by regular excavation, mostly in a compact set of trenches. Cremation clearly proved to be the dominant burial rite. Only four inhumations were uncovered, either directly at the base of the mounds or in the spaces between the mounds. The barrows were for the most part circular in plan and with the exception of ones that were empty and hence considered as cenotaphs, they contained cremation burials, chiefly located under a mound. The form of the grave as well as the burial rite are in keeping with the funerary customs of the Scandinavian cultural milieu [...]. The Scandinavian origins of the individuals buried under the circular mounds at the Swielubie cemetery are borne out not only by the form of the burial, but also by the treatment of the body and the nature of the grave goods. These are significant diagnostic characteristics permitting an ethnic identification of the deceased" (Łosiński 2008, p. 163). 
wieleckie. Nie jest możliwe stwierdzenie, które z innych grobów były grobami słowiańskimi. Z tego, co wiadomo o zwyczajach funeralnych Skandynawów, wynika, że groby ciałopalne, bez wyposażenia, są wystarczająco często spotykane na cmentarzyskach rodzinnych, aby uznać te w Świelubiu także za groby skandynawskie. Analogiczną drogę wnioskowania obrał W. Łosiński w swoich rozważaniach na temat podobnych grobów z duńskiego emporium Groß Strömkendorf na wybrzeżu Obodrytów (Łosiński 2008, s. 166-167).

\section{ATRYBUCJA PRZEDMIOTÓW Z GROBÓW}

O skandynawskich zabytkach odkrytych w kilku grobach świelubskich pisałem w artykule, w którym próbowałem w syntetyczny sposób pokazać obecność skandynawską na Pomorzu w epoce wikingów. Podkreślając znaczenie tych przedmiotów dla zrozumienia wydarzeń zachodzących na Pomorzu w IX w., przeprowadziłem identyfikację zabytków jako pochodzących ze środkowej Szwecji, a dokładniej mówiąc, z emporium handlowego Birka (Duczko 2000, s. $31 \mathrm{nn}$.).

Emporium to powstało około połowy VIII w. i działało przez dwa stulecia, stanowiąc najważniejsze centrum handlowo-rzemieślnicze w tej części Skandynawii. Bliskie kontakty z krajami skandynawskimi oraz z Europą Zachodnią i Wschodnią, o których informują nas zwięzłe przekazy źródeł pisanych, a które w sposób niezwykle liczny wzbogaca materiał archeologiczny, pokazują, dlaczego emporium na wyspie Björkö stało się dla badaczy zajmujących się epoką wikingów jednym z najważniejszych miejsc studiów. Stało się to dzięki zbadaniu prawie 1200 grobów $\mathrm{z}$ cmentarzysk znajdujących się na wyspie (ryc. 2). Samo zbadanie byłoby niewystarczające, gdyby nie publikacja autorstwa archeologa z Lundu Holgera Arbmana. Dwa tomy Birki I, opublikowane w 1940 i 1943 r., zawierające opis każdego grobu i ilustracje przedmiotów z tych grobów, objawiły bogactwo i różnorodność epoki wikingów najpierw dla specjalistów, a dopiero potem dla szerokiej publiczności, na początku europejskiej, później globalnej. Znaczenie materiałów grobowych z Birki dla poznania epoki wikingów jest wyjątkowe. Bezcenna jest bowiem możliwość studiowania źródeł od początków VIII w., przez IX aż do początku 2 poł. X w., a obecność różnego rodzaju pochówków - szkieletowych w grobach komorowych, w których chowano miejscowe elity, oraz standardowych, tak ciałopalnych, jak szkieletowych, pod kopcami lub bez nich - pozwala na zorientowanie się w różnorodności kultury materialnej nie tylko Szwedów, ale też Duńczyków i Norwegów.

Doceniając znaczenie Birki dla poznania cywilizacji epoki wikingów, nie powinniśmy zapominać o znaczeniu licznych mniejszych lub większych stanowisk z całej Szwecji, które dostarczyły obfitego materiału zabytkowego, dopełniającego obraz zdominowany przez materialne źródła z emporium na wyspie Björkö. Na cmentarzysku, używanym przez kilkaset lat, chowano ludzi żyjących w najbliższym sąsiedztwie. W tym materiale rozpoznajemy przedmioty znane z Birki, ale także inne, na pewno produkowane lokalnie, ale zawsze trzymające się raz ustalonego sposobu prezentacji świata, będącego szerokim interskandynawskim związkiem kulturo- 
Łosiński concluded later that not only Scandinavians were buried at the cemetery in Swielubie: "It is unjustified to think that no one but the Scandinavians was buried at the cemetery. Three different coexisting burial traditions have been identified at Swielubie [...]. The bulk of the barrow graves are to be linked to a Scandinavian tradition. However, there is one mound that is clearly not in this standard. It was a cremation deposited at the summit of a mound surrounded by a ditch on a square plan. This mound appears to be a derivative of ideas penetrating into the coastal province from the southern territories of the Western Slavs [...]. The model quickly spread throughout the northern part of our country [Poland] and in northern Polabia [...]. Also discovered at Świelubie, mainly in the inter-barrow spaces, but also at the base of the mounds, were grave pits of large size with cremation burials, occasionally also with evidence of inhumation typical of graves of the Alt Käbelich type [...]. This form of grave may be classified as typical of the Slavs who lived in territories formerly believed to be part of the non-burial sepulchral sphere [...]. Therefore, the cemetery at Świelubie would be a burial ground specifically for the Scandinavian newcomers, but open also to the Slav inhabitants of the Bardy-Świelubie territorial community [...]. The individuals buried here would have been residents of the stronghold and the satellite villages, who had been in closer relations with the Northerners. This type of emerging human relations must have led to a gradual acculturation of the newcomers [...]. Whatever the case may be, there is no data to indicate that a larger group of descendants of the old Scandinavian community was still living in the lower run of the Parsęta in the $10^{\text {th }}$ c." (Łosiński 2008, p. 165).

Łosiński concluded thus that the cemetery, which he originally assigned to the Scandinavians alone, was actually in use also for selected members of local social groups. As for the pit features of the Alt Käbelich type, they were the remains of unidentified ritual behavior that did not lead to burial. Funerary remains of this kind are encountered most frequently in territory occupied by the Veleti tribes. It is not possible to ascertain which of the other types of graves could be described as Slavic. Knowledge of Scandinavian burial customs indicates that cremation burials devoid of grave goods are sufficiently common in family cemeteries in the land of their origin to support the view that they could also be Scandinavian at Swielubie. Łosiński presented analogous reasoning with regard to similar graves from the Danish emporium of Groß Strömkendorf on the part of the coast occupied by the Obodrites (Łosiński 2008, pp. 166-167).

\section{ATTRIBUTION OF ARTIFACTS FROM THE GRAVES}

The Scandinavian artifacts from the few graves at Świelubie were presented in an article intended to give a synthetic view of the Scandinavian presence in Pomerania during the Viking Age. Emphasizing the importance of these artifacts for understanding events in $9^{\text {th }} \mathrm{c}$. Pomerania, the author was able to identify these artifacts as coming from central Sweden, specifically from the trade emporium of Birka (Duczko 2000, pp. 31ff.). 


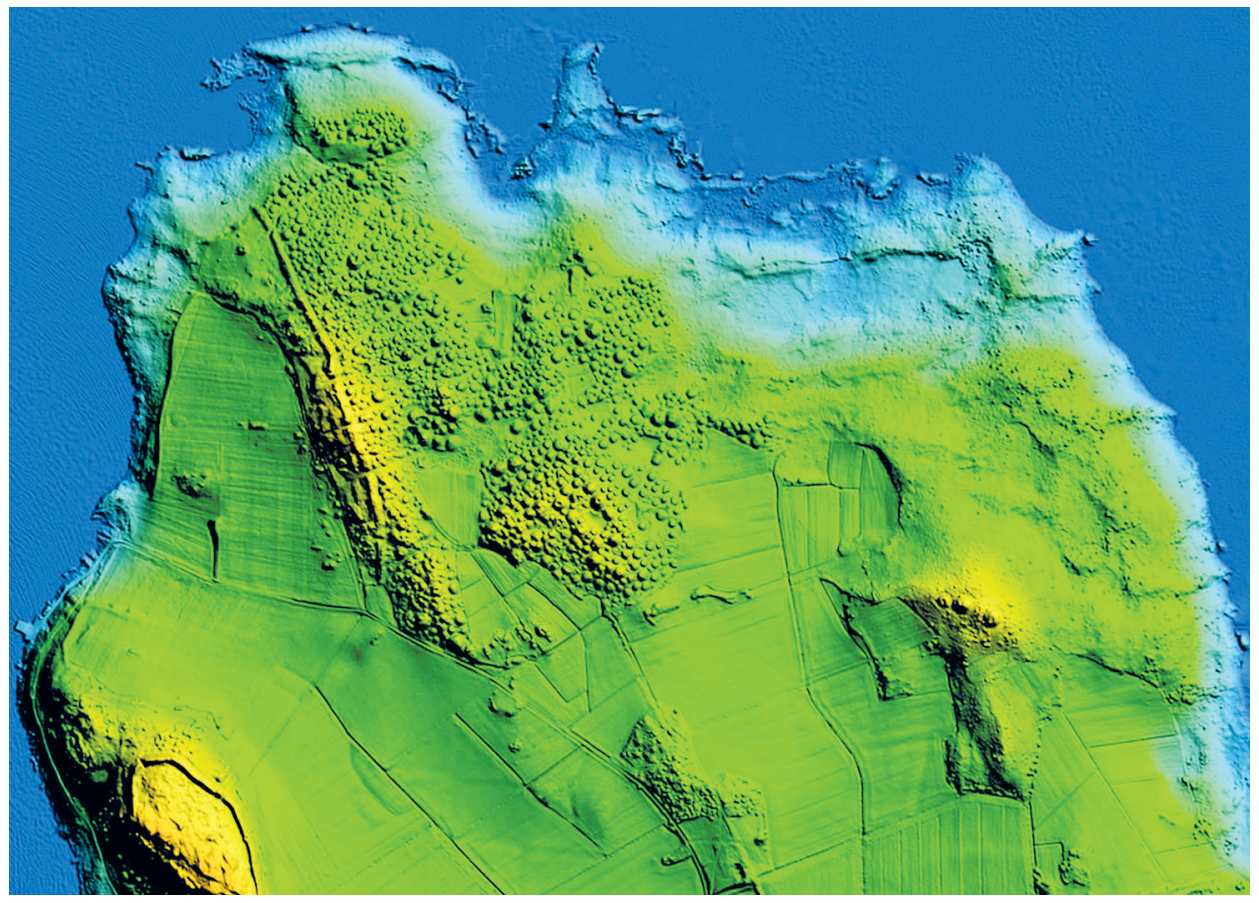

Ryc. 2. Birka na wyspie Björkö, środkowa Szwecja

W centrum - główne cmentarzysko, Hemlanden; na prawo na wzgórzu z kopcami - Ormknös na lewo na dole - Borg z cmentarzyskami.

Wg Riksantikvarieämbetet, Stockholm

Fig. 2. Birka on the island of Björkö, central Sweden

The main cemetery, Hemlanden, in the center; Ormknös on the hill with the mounds on the right; Borg with the cemeteries at the bottom on the left.

After Riksantikvarieämbetet, Stockholm

wym, opartym na starych tradycjach i nabywanych z czasem w trakcie migracji nowościach dostosowywanych do miejscowych potrzeb. Takim zestawem skandynawskich przedmiotów są znaleziska grobowe ze Świelubia. Ich formy, dekoracje, funkcje społeczne były obce Słowianom żyjącym nad rzeką Parsętą. Kilkaset kilometrów na północny wschód od pomorskiego wybrzeża, w środkowej Szwecji, były natomiast materialną manifestacją ideologii społecznej i ważną częścią statusu wierzeń religijnych (Duczko 2016a).

\section{ZAPINKI}

Przedstawianie przedmiotów skandynawskich pochodzących z grobów w Świelubiu chciałbym zacząć od zapinek, czyli tych ozdób, których wyjątkowość na zachodnim wybrzeżu Bałtyku zwróciła uwagę badaczy. Zapinki z funkcją pod- 
Birka came into being about the middle of the $8^{\text {th }} \mathrm{c}$. and existed for two hundred years. At the time, it was the most important craft and trade center in this part of Scandinavia. Close ties with Scandinavian lands as well as western and eastern Europe, mentioned only briefly in the written sources but strongly substantiated by the archaeological record, reveal why the emporium on Björkö island became one of the most important study fields for researchers into the Viking Age. Close to 1200 graves from the cemetery on the island were excavated (Fig. 2), but the exploration itself would have hardly been sufficient to shore up this interest without Holger Arbman's two-volume publication from 1940 and 1943. This Lund archaeologist described each of the graves, illustrating all of the individual finds to show the richness and diversity of the Viking Age, first to specialists and later to a general public, at first European and then global. The significance of the funerary material from Birka for understanding the Viking Age is exceptional. The opportunity to study sources from the early $8^{\text {th }}$ through the $9^{\text {th }}$ and all the way to the beginning of the $2^{\text {nd }}$ half of the $10^{\text {th }} \mathrm{c}$. is invaluable in itself, while the presence of burials of a different kind, from inhumations in chamber tombs intended for the local elite to standard cremations and inhumations graves with or without mounds, gives a good idea of the material culture of the Swedes, but also of the Danes and Norwegians.

Even as one appreciates the importance of Birka for a broad view of civilization in the Viking Age, one should keep in mind the many great and small sites all over Sweden, which have yielded extensive artifactual material to complement the picture made up of the finds from the emporium on Björkö island. The people buried in the cemetery, which remained in use for a few hundred years, came from the neighborhood. Artifacts include objects known from Birka, but also others, most certainly produced locally, always presenting an accepted world view of a wide inter-Scandinavian cultural union based on old traditions and novelties assumed in the course of the migrations and adapted to local needs. The finds from the Swielubie cemetery constituted just such a set of Scandinavian artifacts. Their form, decoration and social function were foreign to the Slavs from the banks of the Parsęta, but a few hundred kilometers northeast of the Pomeranian coast, in central Sweden, they were a material manifestation of social ideology and an important component of religious beliefs (Duczko 2016a).

\section{BROOCHES}

The presentation of grave furnishings from the Świelubie cemetery should start with the brooches, a unique kind of personal accessory that first attracted the attention of researchers to this part of the Baltic coast. Thanks to their frequent presence especially in burial contexts, these fastenings, which were part of female dress, are for archaeologists an important dating source, determining the time of use. Three kinds of brooches were discovered at Świelubie and each one brings information about its origins. 
trzymywania części stroju kobiecego, dzięki częstemu występowaniu, zwłaszcza w kontekstach funeralnych, są dla archeologów ważnym materiałem źródłowym pozwalającym na ustalenie czasu ich używania. W Świelubiu odkryto trzy rodzaje zapinek i każdy z nich zawiera informacje umożliwiające ustalenie, skąd pochodzą.

\section{Zapinka typu pałąkowo-tarczowego}

Wśród zapinek epoki wikingów znajduje się jeden rodzaj mający długą tradycję używania w stroju kobiet germańskich na Kontynencie i w Skandynawii. Typ ten nosi nazwę pałąkowo-tarczowy (po szwedzku ryggknappspänne; po niemiecku Bügelscheibenfibel, po angielsku disc-on-bow brooch). Zapinka taka składa się z górnej części w formie prostokąta i dolnej owalnej zakończonej częścią okrągłą. Części te są łączone łukiem, na którego szczycie umieszczano okrągłą tarczę. Forma nawiązuje do ozdób z okresu wędrówek ludów, zwłaszcza z VI w., kiedy złotnicy u różnych germańskich ludów produkowali dla ich elit luksusowe egzemplarze (Olsen [2005/2006] 2006). Zapinki tego typu stały się popularne w całej Skandynawii, a szczególnie na dwóch wyspach bałtyckich, Bornholmie i Gotlandii. Konserwatywna populacja na tej ostatniej podtrzymała zwyczaj ich noszenia przez cały VII w. i później. W epoce wikingów zapinki były czasami rozbudowywane do groteskowych rozmiarów, niekiedy ponad $30 \mathrm{~cm}$ długości, i używane do XII w. (Thunmark-Nylén 2006a; 1998, tabl. 31-52).

Zapinki przedstawiały ważny element stroju. Przez swoją wielkość, kolory pozłacany brąz, detale wykonane z czerwonych granatów a także z białych, surowców organicznych: zwykle z kości, czy nawet macicy perłowej - prezentowały się nie tylko jako dzieła sztuki złotniczej, które noszono dla prestiżu, ale także jako przedmioty magiczne, amulety, mające zapewnić noszącym szczęście (Duczko 2016a, s. 95).

Gotlandzkie zapinki występują bardzo rzadko poza wyspą, na przykład w środkowej Szwecji są znane tylko w dwóch egzemplarzach - jeden $\mathrm{z}$ cmentarzyska w Ruda, Skedevi, Östergötland, i jeden z kobiecego grobu łodziowego z końca VIII w. z cmentarzyska w Tuna i Badelunda, Västmanland (Nylén, Schönbäck 1994a, s. 38-41; ci sami 1994b, s. 94-99).

W Świelubiu takie zapinki nie zachowały się w całości, zostały z nich dwa detale. Jeden to element $\mathrm{w}$ formie okrągłego guza $\mathrm{z}$ trójkątem na powierzchni i mniejszym guzem na szczycie (ryc. 3a; Duczko 2000, s. 32, ryc. 7c). Takie elementy były umieszczane na powierzchni zapinki, dwa na części górnej i dwa na dolnej, a jeżeli chodzi o formę, to analogie najbliższe do guza świelubskiego można zobaczyć na zapince z Grötlingbo, Gotlandia (ryc. 3b; Thunmark-Nylén 1998, tabl. 44). Znaleziska takich luźnych guzów są znane na przykład z wikińskiego portu w Paviken na Gotlandii (Lundström 1981, s. 91-92).

Drugim elementem mogącym być częścią zapinki dyskutowanego typu znalezionym w Świelubiu jest długa igła z kapturem na jednym końcu. Odkrywca uznał ją za część konstrukcji owalnej zapinki z grobu 24 (patrz dalej; Łosiński 1972, ryc. 101, na lewo dół), ale szwedzki archeolog Ingmar Jansson w swoim przeglądzie owal- 

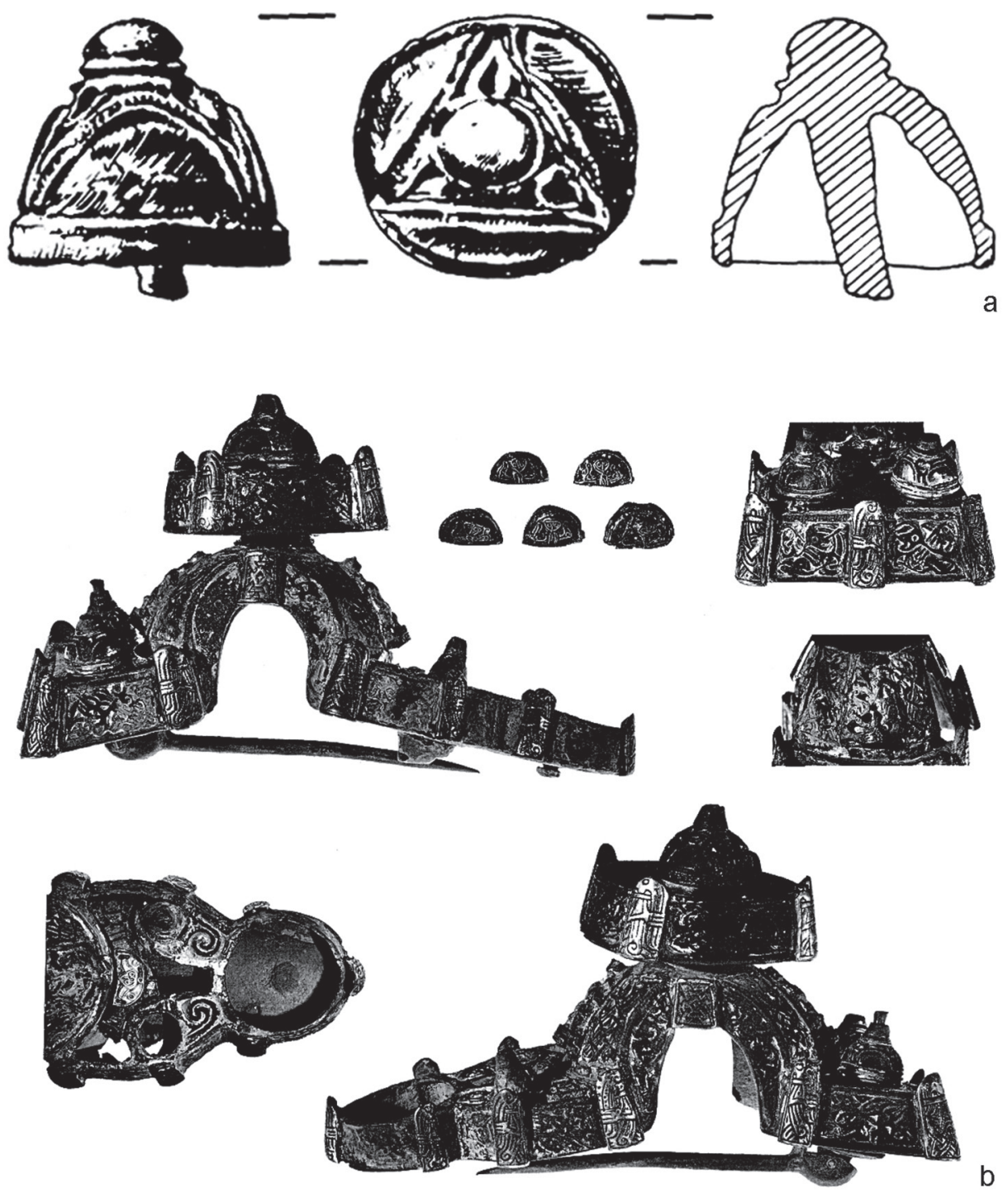

Ryc. 3. Zapinki

a - guz z zapinki pałąkowo-tarczowej ze Świelubia; b - zapinka pałąkowo-tarczowa z Grötlingbo, Gotlandia, Szwecja.

Wg Duczko 2000, ryc. 7c (a); Thunmark-Nylén 1998, ryc. 44 (b)

Fig. 3. Brooches

a - knob from a disk-on-bow brooch from Świelubie; b - disk-on-bow brooch from Grötlingbo, Gotland, Sweden. After Duczko 2000, Fig. 7c (a); Thunmark-Nylén 1998, Fig. 44 (b) 

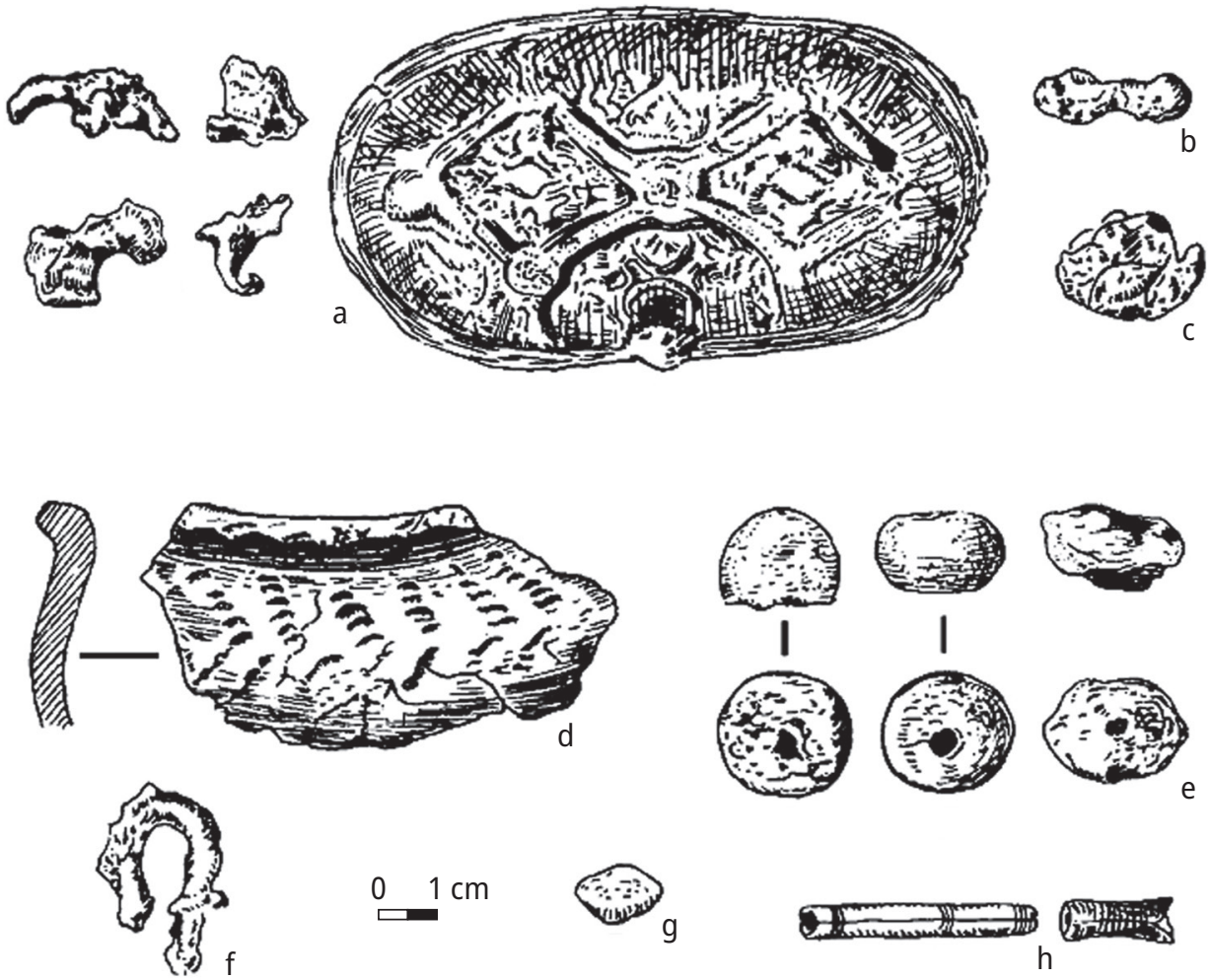

Ryc. 4. Świelubie, grób z kurhanu I z 1897 r. zawierający jedną owalną zapinkę typu JP 37:3.

Wg Żaka 1963, ryc. 67

Fig. 4. Swielubie, grave in mound I from 1897, with one oval brooch of JP 37:3 type.

nych zapinek rozpoznał ją jako igłę z zapinki pałąkowo-tarczowej (Jansson 1985, s. 116). Jeżeli rozpoznanie jest prawidłowe, to znaczy to, że ze Świelubia mamy dwa elementy zapinek używanych na Gotlandii w IX w.

\section{Zapinki owalne}

Pary zapinek owalnych, kiedyś zwanych żółwiowatymi, odlewanych w brązie, należą do najbardziej typowych ozdób skandynawskich kobiet epoki wikingów (Jansson 1985). Ich najstarsze, małych rozmiarów egzemplarze, pojawiają się w Danii na początku VIII w., przez trzy stulecia stają się coraz większe i coraz popularniejsze w całej Skandynawii, aby w końcu X w., pod naciskiem szerzącej się ideologii chrześcijańskiej, wyjść z użycia. Norweski archeolog Jan Petersen opublikował w 1928 r. zestaw ozdób typowych dla epoki wikingów, w tym zapinki owalne, 


\section{Disk-on-bow brooches}

One of the Viking Age types of brooches that has a particularly long tradition of serving as a dress fastening for Germanic women in both Europe and Scandinavia is the disk-on-bow type (Swedish ryggknappspänne; German Bügelscheibenfibel, Polish zapinka pałąkowo-tarczowa). It is made up of an upper part in the form of a rectangle and a lower, oval part terminating in a circular element, joined by an arched piece with a circular disk on top. The form refers to ornaments from the Migration Period, especially the $6^{\text {th }}$ c., when luxury items of this kind were being produced by goldsmiths for the Germanic elites (Olsen [2005/2006] 2006). Brooches of this kind were a familiar sight throughout Scandinavia and on the two Baltic islands, Bornholm and Gotland, in particular. The conservatively-minded population of the latter island continued to wear this kind of dress fasteing throughout the $7^{\text {th }} \mathrm{c}$. and later. In the Viking Age, these brooches took on sometimes grotesque dimensions, occasionally more than $30 \mathrm{~cm}$ in length, and were used until the $12^{\text {th }} \mathrm{c}$. (Thunmark-Nylén 2006a; 1998, Pls 31-52).

The brooches were an important dress accessory. They often constituted goldsmithing masterpieces thanks to their size and colors - gilded bronze, details of red garnets as well as white organic substances, usually bone but also nacre - worn as a sign of the owner's prestige, but also as magical objects, amulets worn for good luck (Duczko 2016a, p. 95). Gotland brooches are rarely found outside the island; two are known, for example, from central Sweden, from the cemetery at Ruda, Skedevi, Östergötlandand from a female grave from the end of the $8^{\text {th }} \mathrm{c}$. from the cemetery at Tuna i Badelunda, Västmanland (Nylén, Schönbäck 1994a, pp. 38-41; iidem 1994b, pp. 94-99).

The evidence from Świelubie includes two component parts of such brooches. One of these is a round knob with a circle on the surface and smaller knob on top (Fig. 3a; Duczko 2000, p. 32, Fig. 7c). Elements like this one used to be placed on the brooch surface, two each in the upper and lower parts. As for the form, the nearest parallels for the Świelubie knob are the decorations of a brooch from Grötlingbo, Gotland (Fig. 3b; Thunmark-Nylén 1998, Pl. 44). Loose knobs of this sort are known, for example, from the Viking port of Paviken in Gotland (Lundström 1981, pp. 91-92).

The other possible component part of a disk-on-bow brooch found at Świelubie is a long pin with a hood at one end. The excavator believed it to be part of an oval brooch from grave 24 (see below; Łosiński 1972, Fig. 101, bottom left), but in his review of oval brooches Swedish archaeologist Ingmar Jansson recognized it for what it is (Jansson 1985, p. 116). Assuming the identifications are correct, we would have two component elements of a kind of brooch that was in use on Gotland in the $9^{\text {th }} \mathrm{c}$.

\section{Oval brooches}

Pairs of oval brooches cast in bronze (once called turtle-shaped) are among the most typical accessories of Scandinavian women of the Viking Age (Jansson 


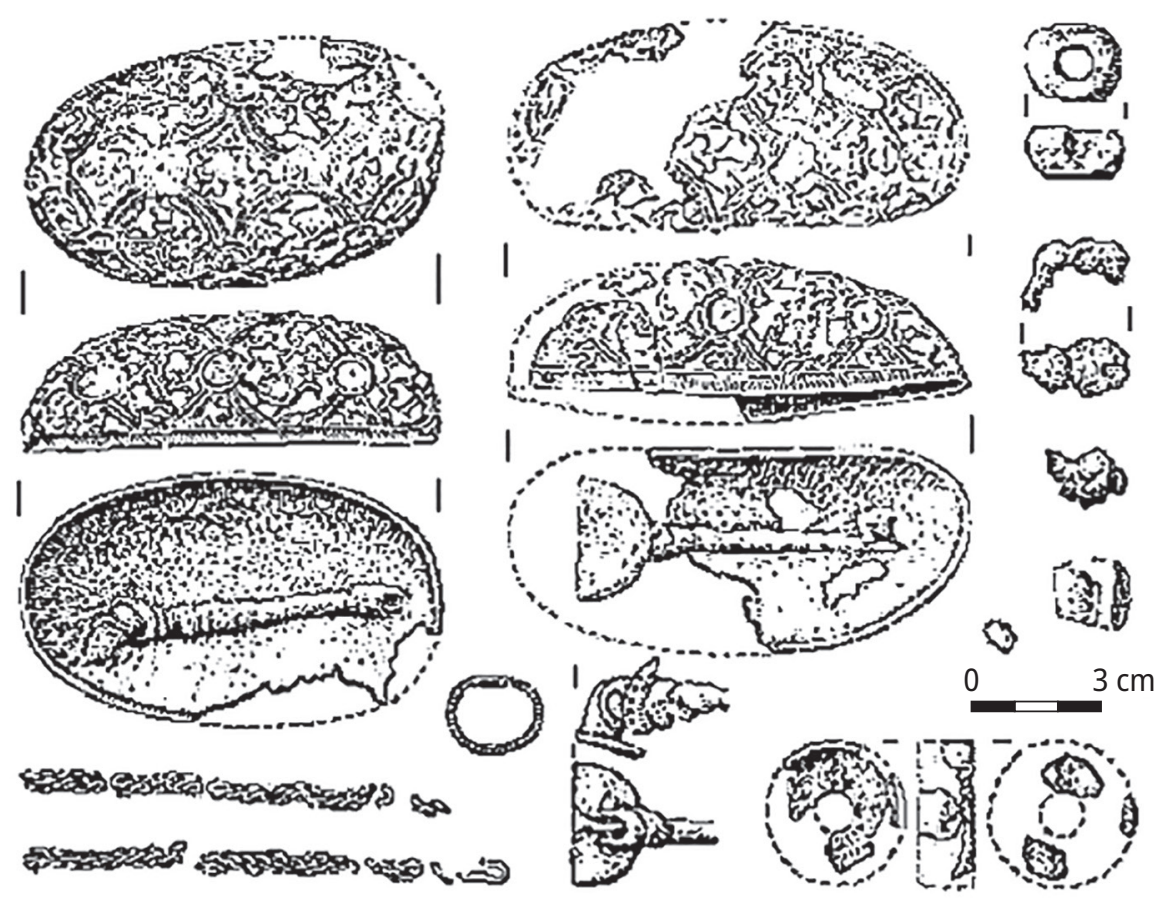

Ryc. 5. Świelubie, grób 24, owalne zapinki

Na dole po środku - część igły, prawdopodobnie należącej do zapinki pałąkowo-tarczowej.

Wg Łosińskiego 1972, ryc. 101

Fig. 5. Świelubie, grave 24, oval brooch

Part of a pin, most probably from a disk-on-bow brooch, at bottom center.

After Łosiński 1972, Fig. 101

które stosowane były w parze do podtrzymywania długiej sukni. Petersen podzielił te zapinki na pięćdziesiąt dwa typy z podtypami (Petersen 1928), a podział ten został utrzymany przez Ingmara Janssona, który w swojej pracy doktorskiej opracował zapinki z grobów w Birce, jednocześnie prezentując materiał skandynawski (Jansson 1985).

W grobach świelubskich znaleziono cztery owalne zapinki: po jednej w dwóch grobach - I, 21 - oraz dwie w grobie 24. Grób I dostarczył pierwszą owalną zapinkę, tym samym dając początek studiom nad obecnością skandynawską nad Parsętą (ryc. 4; Żak 1963, s. 68 nn., nr 89, ryc. 67; Łosiński 1972, s. 29, ryc. 99d). Zapinkę można zidentyfikować jako typ JP 37:3, wariant b (Jansson 1985, s. 47, ryc. 39b; 40b). Typ 37 należy do najpopularniejszych, a znaleziska fragmentów form odlewniczych w Birce ukazujących charakterystyczne detale konstrukcyjne motywu wskazują, gdzie odbywała się produkcja tych ozdób (Jansson 1985, s. 51). 


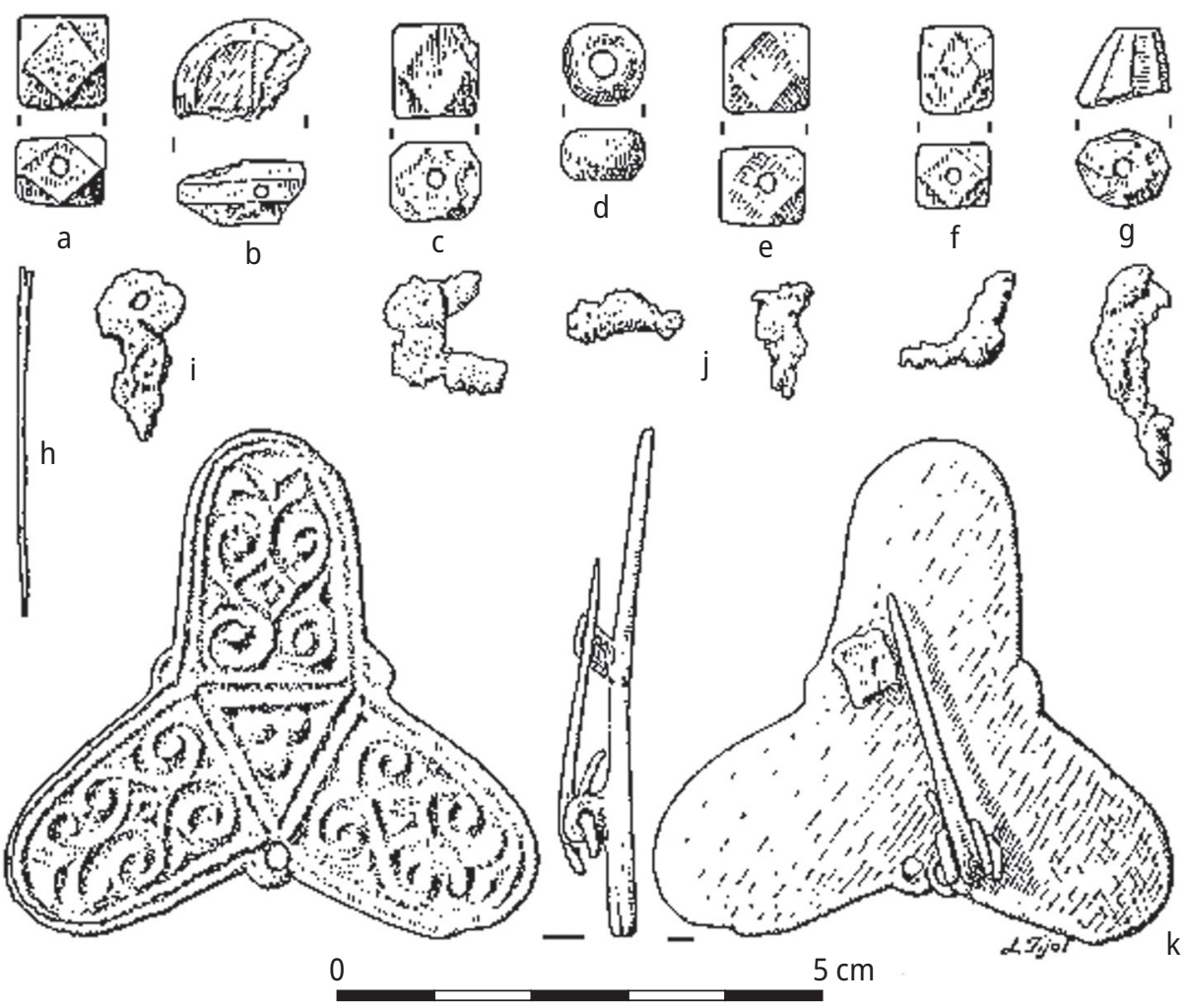

Ryc. 6. Świelubie, grób 10, pochówek 7, trójlistna zapinka.

Wg Łosińskiego 1972, ryc. 100

Fig. 6. Świelubie, grave 10, burial 7, trefoil brooch.

After Łosiński 1972, Fig. 100

1985). The oldest small-size examples appeared in Denmark at the beginning of the $8^{\text {th }} \mathrm{c}$., becoming increasingly larger and more common in Scandinavia in the next 300 years, only to cease being used under pressure from spreading Christian ideology at the close of the $10^{\text {th }} \mathrm{c}$. In 1928, Norwegian archaeologist Jan Petersen published a set of typical Viking-Age accessories, including oval brooches, pairs of which were used to fasten long robes. Petersen distinguished 52 types with variants (Petersen 1928), a classification retained by Ingmar Jansson in his doctoral dissertation on the Birka brooches, which was a presentation of the Scandinavian material (Jansson 1985).

Four oval brooches were found in the Świelubie graves: one each in two graves $(\mathrm{I}, 21)$ and two in grave 24 . The oval brooch from grave I triggered studies of Scandinavian presence on the banks of the Parsęta (Fig. 4; Żak 1963, p. 68ff., no. 89, Fig. 67; 
Pozostałe okazy odkryto w trakcie badań W. Łosińskiego. Pod kopcem nr 21, $\mathrm{w}$ ciałopalnym, podwójnym pochówku znaleziono ułamki zapinki, z których zestawienia rekonstrukcyjnego wynikało, że była to fibula typu JP 37:2 lub 42 (Łosiński 1972, s. 247, ryc. 99b). Z tak małych fragmentów trudno otrzymać wiarygodną rekonstrukcję, ale wygląd jednego $\mathrm{z}$ nich, górnego, pozwala zaryzykować identyfikację z typem JP 42, na przykład z zapinką z grobu szkieletowego Bj $632 \mathrm{w}$ Birce (Arbman 1940, tabl. 63:3). Typ ten jest umiejscawiany we wczesnym okresie epoki wikingów, jego egzemplarze występują czasami, bardzo rzadko, w zespołach zabytków z okresu późniejszego, możemy więc występowanie tego typu widzieć przede wszystkim w 2 poł. IX w. (Jansson 1985, s. 172).

Kurhan 24, pod którym znajdowały się dwa ciałopalne pochówki, dostarczył parę dobrze zachowanych, tylko nieco podniszczonych, owalnych zapinek, do których trudno znaleźć bliskie analogie (ryc. 5; Łosiński 1972, s. 247, ryc. 101). Kompozycja dekoracji składająca się z trzech środkowych pól rombowych, czterech bocznych i czterech końcowych medalionów wypełnionych motywami zwierzęcymi, nie jest znana. Być może jest ona kombinacją wziętą z różnych owalnych zapinek, którym najbliżej do typu JP 35, należącego do ozdób z IX w. (Petersen 1928, s. 35, ryc. 39; Jansson 1985, s. 43-46).

Owalne zapinki ze Świelubia należą zatem do typów używanych w Skandynawii w IX w., zwłaszcza w jego 2 połowie. Czy ich użytkowniczki pochodziły ze środkowej Szwecji, z Upplandu? Jest to bardzo możliwe, ponieważ centrum rzemieślnicze w Birce, gdzie znaleziono formy do produkcji takich ozdób, powinno być traktowane jako główny dostarczyciel owalnych zapinek w tej części Skandynawii. Kobiety noszące je a pochowane w Świelubiu przybyły nad Parsetę ze swoimi ozdobami.

\section{Zapinka trójlistna}

Inną formą ozdoby w stroju kobiety skandynawskiej była zapinka trójlistna, nazywana przez archeologów trzecią - obok pary owalnych - którą używano, podobnie jak okazy okrągłe, do spinania koszul i tunik. W odróżnieniu od większości takich ozdób mających swoje pochodzenie w starych, przedwikińskich tradycjach, ta została stworzona w IX w. jako kopia formy, i na początku dekoracji, okucia rzemieni rapci mieczy wojowników frankijskich z czasu panowania Karola Wielkiego (Petersen 1928, s. 93; Capelle 1968; Lennartsson [1997/1998] 1999, s. 484 nn., ryc. 16a). J. Petersen, mając dostęp do 84 norweskich egzemplarzy, uporządkował trójlistne zapinki według rodzaju dekoracji, co za nim powtórzyła Brigita Hårdh, systematyzując 23 egzemplarze z dwudziestu grobów z Birki i dzieląc je na sześć grup w zależności od motywów - z uproszczonymi motywami roślinnymi, wyobrażeniami zwierząt oraz prostymi geometrycznymi polami. Zapinki były odlewane w brązie, w kilku rzadkich przypadkach wykonane ze srebra i pokryte dekoracją wykonaną w filigranie (Petersen 1928, s. 93-114; Arbman 1940, tabl. 73-75; Hårdh 1984b; Duczko 1985, s. 91-94).

Trójlistne zapinki były w modzie przede wszystkim w Norwegii i zaraz po niej w Szwecji, zdecydowanie rzadziej w Danii. Dominującą dekorację z motywami 
Łosiński 1972, p. 29, Fig. 99d). The type represented by this brooch is identified as JP $37: 3$, variant b (Jansson 1985, p. 47, Figs 39b; 40b), one of the most common types that was produced at Birka judging by the fragments of casting molds with characteristic structural elements of the decorative motif found there (Jansson 1985, p. 51).

The other three fragments were discovered by Łosiński. Pieces found in a double cremation burial under barrow 21 were reconstructed as a JP 37:2 or JP 42 type brooch (Łosiński 1972, p. 247, Fig. 99b). Reconstructions based on such minute (figure at the top) fragments of an artifact are hardly credible, but the appearance of one of the pieces warrants an identification with type JP 42, e.g., brooch from an inhumation tomb Bj 632 at Birka (Arbman 1940, Pl. 63:3). It is a type from the early Viking Age, found only rarely in later assemblages, hence its dating primarily to the $2^{\text {nd }}$ half of the $9^{\text {th }}$ c. (Jansson 1985, p. 172).

Barrow 24, which marked two cremation burials, yielded a pair of well preserved oval brooches showing evidence of long wear. No direct parallels are known to date (Fig. 5; Łosiński 1972, p. 247, Fig. 101). The composition consisting of three central rhomboidal panels, four lateral medallions and four medallions at the ends, all filled with animal representations, is unparalleled. It may be a combination taken from different oval brooches, which are closest to type JP 35 from the $9^{\text {th }} \mathrm{c}$. (Petersen 1928, p. 35, Fig. 39; Jansson 1985, pp. 43-46).

Therefore, the oval brooches from Świelubie represent types used in Scandinavia in the $9^{\text {th }}$ c., especially in the second half. Could it be that the women who fastened their dress with these clasps came from Uppland in central Sweden? It is very probable, considering that the crafts center at Birka, where molds for casting accessories of this kind have been found, should be treated as the chief supplier of oval brooches to this part of Scandinavia. The women buried at Swielubie brought their dress accessories with them when they came to live on the banks of the Parsęta river.

\section{Trefoil brooch}

The trefoil (three-leaf) brooch is the third kind of fastening, beside the oval brooches which come in pairs and the round brooches, used on tunics and shirts. Unlike most dress accessories of the kind which are rooted in old pre-Viking traditions, this particular form was created in the $9^{\text {th }} \mathrm{c}$. as a copy of the form, and at first also the decoration, of the fittings of leather sword suspenders worn by the warriors of Charlemagne (Petersen 1928, p. 93; Capelle 1968; Lennartsson [1997/1998] 1999, p. 484ff., Fig. 16a). Petersen, who had access to 84 Norwegian examples, classified these brooches by decoration, a system that Brigita Hårdh followed in her work on the 23 specimens from 20 graves at Birka. She divided them into six groups depending on the decoration motif: simplified vegetal, animal images and simple geometrical figures. The brooches were cast in bronze, in a few rare cases made of silver with filigree decoration (Petersen 1928, pp. 93-114; Arbman 1940, Pls 73-75; Hårdh 1984b; Duczko 1985, pp. 91-94).

Trefoil (Three-leaf) brooches were the fashion foremost in Norway and also in Sweden, definitely less in Denmark. Decoration with animal motifs is the predomi- 
zwierzęcymi mają egzemplarze norweskie, zwłaszcza typ JP 97, natomiast na zapinkach szwedzkich, głównie typu JP 90, występuje przede wszystkim ornamentyka spiralna wywodząca się z dekoracji roślinnej (Jansson 1985, s. 164).

Tę szwedzką specjalność reprezentuje zapinka ze Świelubia odkryta w pochówku 7 w obrębie grobu 10 (ryc. 6; Łosiński 1972, s. 247, ryc. 100k; tenże 2003). Należy ona do rzadko występującego typu JP 88, mającego charakterystyczny trójkąt $\mathrm{z}$ trzema okrągłymi wypukłościami w środku. Typ ten włączyła B. Hårdh do swojej grupy 3.1, w której zebrała zapinki trzech typów Petersena (Petersen 1928, s. 100, ryc. 88; Hårdh 1984b, s. 88 nn.; Lennartsson [1997/1998] 1999, s. 580 nn., tabl. 27:4). Typ JP 88 jest znany w trzech egzemplarzach z południowej Norwegii - dwóch z Vestfoldu (Berg, Lille Guldkrone), jednego z Buskerud (Reine) - wszystkie wystąpiły wraz z owalnymi zapinkami z IX w. Tak wczesny egzemplarz reprezentuje jedna zapinka trójlistna z Birki z grobu Bj 559, w którym wystąpiła para zapinek owalnych typu P 27A, mająca dekorację z gripdjuren - „chwytającymi zwierzętami” (Jansson 1985, s. 38 nn.).

\section{ZAWIESZKA-KRZESIWO}

Do jednego z oryginalniejszych przedmiotów, w swojej formie i funkcji, należy zawieszka, której fragment zachował się w grobie $6 \mathrm{w}$ Świelubiu. Jest to wydłużony, odlany $w$ brązie ażurowy element $\mathrm{z}$ uszkiem umieszczonym na szerszej górze (Łosiński 1972, s. 249, ryc. 99a). W pierwotnym stanie fragment ten był jednym z dwóch takich samych elementów, okładzin, między którymi znajdował się żelazny rdzeń podobny w formie, ale większy i płaski, kończący się ostrzem na dole. Ornamentyka na ażurowym elemencie pokazuje w sposób silnie uproszczony połączone ze sobą zwierzęta. Właściwym przedmiotem w zawieszce był żelazny element, służący do krzesania ognia (w językach skandynawskich eldstål); znane nam zawieszki-krzesiwa mają mniej więcej podobną wielkość, około 9-10 cm długości (ryc. 7).

Krzesiwa tego rodzaju występują w środkowej Szwecji, w Norwegii, w Rosji, na Ukrainie i w Polsce. Przyjrzyjmy się najpierw znaleziskom szwedzkim. Największa liczba takich zawieszek odkryta została w grobach cmentarzysk Birki. B. Hårdh w opracowaniu wszystkich rodzajów krzesiw z Birki zebrała zawieszki-krzesiwa w typie 3, występującym w wariantach a, b, c (Hårdh 1984a, s. 156-157). Zawieszki znaleziono w grobach ciałopalnych i szkieletowych, głównie męskich, ale i kobiecych: Bj 99, 379, 456, 558, 655, 918, 991, 1139 i jeden egzemplarz bez informacji o grobie oraz jeden w Bj 558 podobny do egzemplarza z Bj 99 (Arbman 1940, tabl. 145:1-8; tenże 1943, s. 179). Grób Bj 99 był grobem ciałopalnym, w którym między fragmentami metalu i ceramiki znaleziono żelazną ostrogę i trzy dirhemy, a wśród nich jeden tahirydzki z Samarkandy - 832/833 r. Innym ciałopalnym pochówkiem z parą ostróg był grób Bj 1139, niezawierający datujących przedmiotów, zaś w Bj 379 oprócz zawieszki były tylko fragmenty blachy z brązu (Arbman 1943, s. 45, $107 \mathrm{nn}$., $470 \mathrm{nn}$.).

Najbliższe analogie do ażurowego elementu zawieszki-krzesiwa $\mathrm{z}$ grobu 6 w Świelubiu znajdujemy w zawieszkach z Birki, są nimi: znalezisko z nieznanego grobu i egzemplarz z Bj 655. Ten ostatni grób, ze szkieletem w trumnie, zawierał 

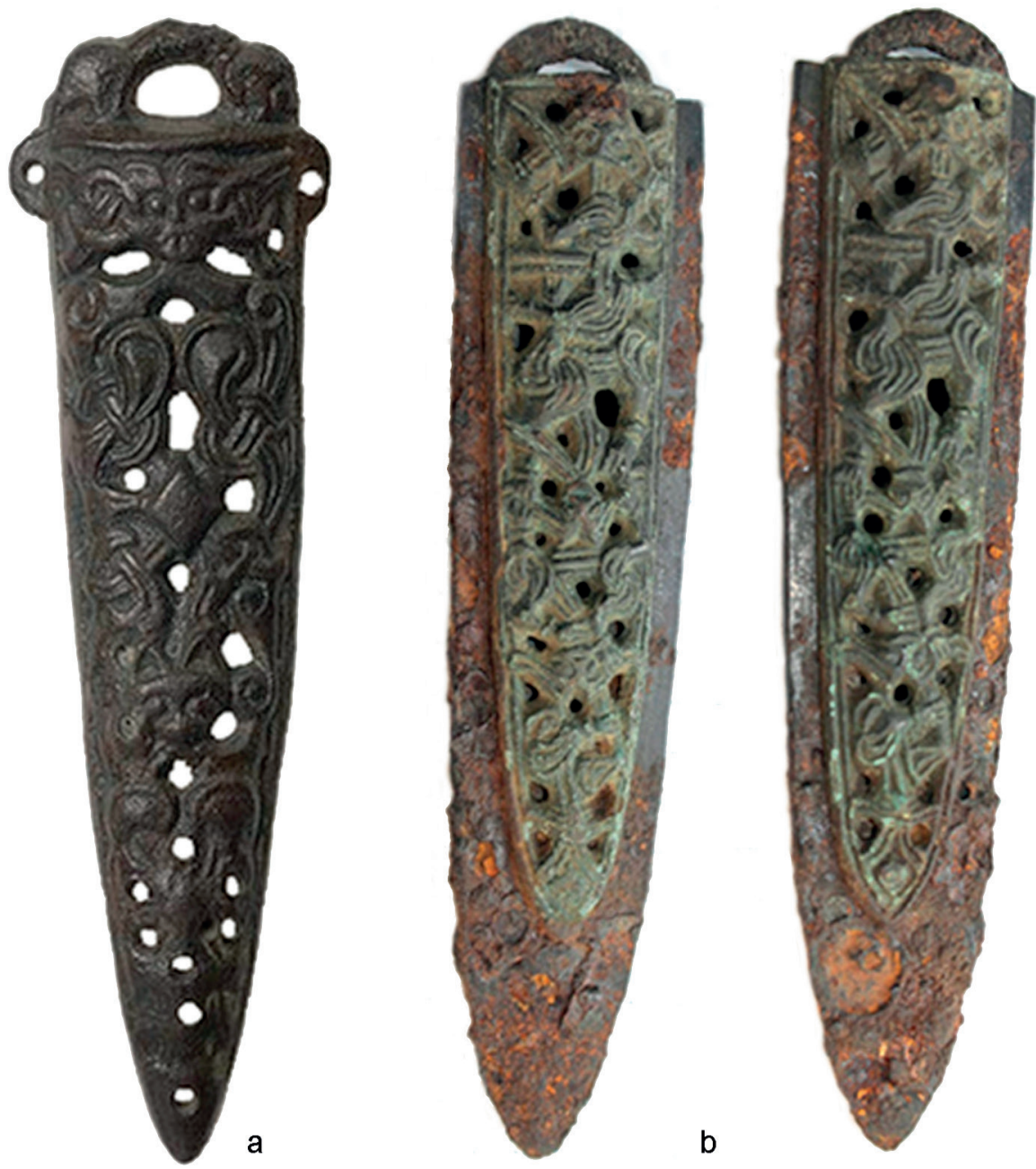

Ryc. 7. Zawieszki-krzesiwa

a - okucie zawieszki-krzesiwa, brąz, znalezisko grobowe, nr inw. 132513, Grötlingbo, Gotlandia, Szwecja; b - nieznane miejsce znalezienia, prawdopodobnie wschodnia Europa.

Foto Historiska Museum, Stockholm (a); Tumuseum.tumblr.com (b)

Fig. 7. Fire striker pendant

a - fire striker pendant fitting, bronze, grave find, inv. no. 132513, Grötlingbo, Gotland, Sweden; b - unknown provenance, probably from eastern Europe.

Photo Historiska Museum, Stockholm (a); Tumuseum.tumblr.com (b) 
parę owalnych zapinek „typu przejściowego między okresem Vendel a okresem wikińskim", z dekoracją zwierzęcą, co należy uznać za wariant stylu III będącego w użyciu na samym początku IX w. (Jansson 1985, s. 19-21; Arbman 1940, tabl. 58:3-6; tenże 1943, s. 229 nn.).

Zawieszkę-krzesiwo odkryto też niedaleko od Birki, na wyspie Helgö, znanej ze swoich unikatowych znalezisk, licznych grup budynków, cmentarzysk, pracowni rzemieślniczych i miejsc kultowych działających tu przez całe pierwsze tysiąclecie naszej ery (Lundström ed. 1988). Był to fragmentaryczny egzemplarz z ciałopalnego grobu A2 z cmentarzyska 116 (Androshchuk 2007, s. 160, ryc. 6:12). Dekoracja na tym egzemplarzu ma najbliższą analogię na zawieszce z birczańskiego grobu Bj 99. Prawie kompletne krzesiwo znaleziono na innym cmentarzysku w Upplandzie w ciałopalnym grobie A5 w Valsta, Norrsunda (Andersson 1997, s. 36, ryc. 28).

Jedynym miejscem w Skandynawii, obok Szwecji, gdzie zawieszki-krzesiwa są obecne, jest Norwegia. Znaleziono tam sześć egzemplarzy i liczba ta nie zwiększyła się od czasu, kiedy je opisał J. Petersen. Te, które miały kontekst, datowane były na IX w. (Petersen 1928, s. 131 nn., ryc. 145, 146, 147). Na południowym wybrzeżu Bałtyku dwa egzemplarze pojawiły się w duńskiej osadzie w Menzlinie nad Pianą (Kleingärtner 2014, s. 442, tabl. 5:4, 5) oraz na wschodzie, za deltą Wisły, w Janowie Pomorskim, na terenie osady emporium Truso (Jagodziński 2010, s. 167 nn., ryc. 259,261$)$. W obu przypadkach są to znaleziska wyjątkowe, nienależące do przedmiotów masowo produkowanych w miejscach odkryć, co nie musi być prawdą jeżeli chodzi o Truso, którego cmentarzysko nadal pozostaje nieodkryte.

Poza Szwecją i Norwegią występowanie kilku krzesiw omawianego typu jest stwierdzone na terenach fińskich (Nordman 1924, s. 116 nn.) i w dwóch miejscach w Europie Wschodniej. Jedno z nich to Sarskoje gorodiszcze (Сарское городище) nad jeziorem Nero, przy górnej Wołdze, na obszarze zamieszkanym przez ugrofiński lud Meria. Gród był zajęty od IX w. przez grupę Skandynawów, którzy, sądząc po odkrytych tu przedmiotach, m.in. zawieszce-krzesiwie, pochodzili ze środkowej Szwecji (Duczko 2006, s. 160 nn.; Hedenstierna-Jonson 2001, s. 68 nn., ryc. 4:1). Drugie miejsce znajduje się na Ukrainie, $15 \mathrm{~km}$ od Czernihowa, przy wsi Szestowica (Шестовица), na prawym brzegu rzeki Desny. W X w. istniał tam ośrodek z grodem i osadą, w której żyli Skandynawowie z rodzinami, o czym świadczy bogaty materiał zabytkowy i pochówki (Duczko 2006, s. 201, ryc. 71-76). O okolicznościach, w jakich odkryto krzesiwo w Szestowicy, niestety brak informacji, a znamy je ze zdjęcia przedmiotu dostępnego w Internecie, gdzie pojawiają się takie krzesiwa, prawdopodobnie znalezione w Europie Wschodniej.

Gdzie produkowano krzesiwa omawianego tu typu? Idea formy zawieszki-krzesiwa mogła być przejęta z okuć końcówek rzemieni do pasa czy uprzęży końskiej, jak to widzimy na egzemplarzach z grobu $110 \mathrm{z}$ cmentarzyska z Ihre, Hellevi na Gotlandii, datowanym na wczesną 1 poł. X w. (Stenberger [1961] 1962, s. 44, ryc. 43); prawie identyczne końcówki i kwadratowe okucia ze zwierzęcą dekoracją pochodzą też ze znanego norweskiego grobu z Borre. Ponieważ brązowe okucia-krzesiwa są ażurowe, możemy również zwrócić uwagę na ażurowe brązowe końcówki rzemieni o podobnej formie i ze zwierzęcą ornamentyką, znalezione w niewiadomym miejscu 
nant form on the Norwegian brooches, especially type JP 97, while the Swedish examples, mainly type JP 90, show a preference for spiral ornamentation derived from plant motifs (Jansson 1985, p. 164).

The brooch from Świelubie, discovered in burial 7 from within barrow 10, shows this Swedish specialty (Fig. 6; Łosiński 1972, p. 247, Fig. 100k; 2003). It represents a rare type, JP 88, with a characteristic triangle and three round knobs in the center. Hårdh included this type in her group 3.1 which collects three of Petersen's types (Petersen 1928, p. 100, Fig. 88; Hårdh 1984b, pp. 88ff.; Lennartsson [1997/1998] 1999, pp. 580ff., Pl. 27:4). Type JP 88 is known from three brooches coming from southern Norway: two from Vestfold (Berg, Lille Guldkrone) and one from Buskerud (Reine); all three were found in context with oval brooches of the $9^{\text {th }}$ c. One of the Birka brooches from grave Bj 559 is also an early example, occurring together with a pair of oval brooches of type P 27A; it is decorated with a gripdjuren "gripping-beast" image (Jansson 1985, pp. 38ff.).

\section{FIRE STRIKER PENDANT}

The cast bronze pendant, a fragment of which was preserved in grave 6 at Swielubie, is one of the most unique finds in terms of its form and function from the cemetery. It is an elongated element with openwork decoration and a suspension loop attached to the wider top part (Łosiński 1972, p. 249, Fig. 99a). It was originally one of two identical pieces constituting the outer lining of a piece of iron of similar shape, sandwiched in between, but larger and flat, ending in a point at the bottom. The openwork ornament is a stylized representation of animals joined together. The iron used as a fire striker was the object proper here (eldstål in Scandinavian); the known fire striker pendants are more or less of the same size, approximately 9-10 cm long (Fig. 7).

Fire strikers of this kind are known from central Sweden, Norway, Russia, Ukraine and Poland. The largest number of such pendants in Sweden was discovered in graves of the Birka cemetery. Hardh collected all the fire striker pendants from this cemetery in her type 3 with three variants a, b, c (Hårdh 1984a, pp. 156-157). The pendants were found in both cremation and inhumation burials, mainly of men, but women were also represented: Bj 99, 379, 456, 558, 655, 918, 991, 1139 and one example without information about the grave, one example from $\mathrm{Bj} 558$ similar to that from Bj 99 (Arbman 1940, Pl. 145:1-8; idem 1943, p. 179). Grave Bj 99 was a cremation; included among the pieces of metal and pottery found in it was an iron spur and three dirhams, one of which was a Tahirid coin from Samarkand struck in $832 / 833$. Another cremation burial that contained a pair of spurs was grave Bj 1139, which however did not have any dating material. Finally, grave Bj 379 yielded only some pieces of bronze sheet metal beside a fire striker pendant (Arbman 1943, pp. 45, 107ff., 470ff.).

Similar objects from Birka are the nearest parallels for the openwork bronze fitting of the fire striker from grave 6 at Świelubie. These are a find from an unknown 
na Gotlandii oraz na ażurowe zawieszki w formie podobnej do krzesiw, jakie były popularne na Gotlandii w IX w. (Thunmark-Nylén 1998, tabl. 167, 266).

Biorąc pod uwagę wpływy z Gotlandii na powstanie zawieszek-krzesiw, możemy jednak stwierdzić ich brak w typowych gotlandzkich zestawach ozdób i tym samym uznać środkową Szwecję za obszar nie tylko używania takich przedmiotów, ale także ich produkcji.

\section{POSAMENT (PASAMON)}

Od tak ważnych dla naszych rozważań zapinek przenieśmy uwagę na ozdoby o szczególnym wyglądzie i o szczególnej funkcji. Chodzi o przedmioty wykonane $\mathrm{w}$ technice posamentowej. Jest to zdobnictwo o nazwie wziętej z języka francuskiego - possament, dosłownie „robota sznurowa”, używane w epoce wikingów przy tworzeniu dekoracyjnej części stroju skandynawskiego. Przez dłuższy czas akceptowana była idea szwedzkiej archeolog Ingi Hägg (1983) łączącej posament z luksusowymi ubiorami wschodniego, przede wszystkim bizantyjskiego pochodzenia, mającymi wskazywać na wysoką rangę społeczną noszącego dane ubranie. Studia badaczy tekstyliów wykazały braki w tym rozpoznaniu. Na przykład supły posamentowe odkrywane w pochówkach szkieletowych nie miały związku ze strojem, lecz z torbami, a badania technik produkcji pokazały, że srebrnych drutów, z których te ozdoby były wyrabiane, nie wykonywano $\mathrm{z}$ wąskich pasm metalu, lecz wyciągając druty w ciągarkach. Ta cecha technologiczna jest istotna, ponieważ występuje ona tylko w Szwecji i nie jest znana w wyrobach z Bizancjum (Larsson 2007, s. 69 nn.).

W Świelubiu odkryto dwa supły posamentowe (ryc. 8, na dole; Łosiński 1974; Zoll-Adamikowa 1980, ryc. 5). Podobne do nich znaleziono w dwudziestu grobach na cmentarzyskach w Birce (w grobach męskich, wyjątkowo w kobiecych) i pochówku łodziowym $\mathrm{nr} 12 \mathrm{z} 2$ poł. $\mathrm{X}$ w. $\mathrm{w}$ Valsgärde, wielkiej nekropolii w środkowym Upplandzie, gdzie w łodziach chowano tylko mężczyzn, a także w Starej Uppsali w obiekcie o niepewnej przynależności grobowej (Larsson 2007, s. 80 nn., ryc. 5). Poza środkową Szwecją supły posamentowe pojawiły się w pochówku łodziowym w Ladby, na wyspie Fionii, oraz w najbogatszym grobie komorowym (5/1964) w Hedeby, największym duńskim emporium - oba groby datuje się na późniejszą część 1 poł. IX w. (Larsson 2007, s. 9 nn., 94 nn.).

Groby z supłami na cmentarzyskach Birki należą do pochówków elit i są w większości datowane na $\mathrm{X}$ stulecie - do połowy tego wieku. Odkrycia na innym cmentarzysku Birki pozwalają na starsze datowanie. Cmentarzysko to jest częścią kompleksu Ormknös (ryc. 8, góra), leżącym na wzgórzu, około $800 \mathrm{~m}$ na wschód od wału odgraniczającego wielkie cmentarzysko Hemlanden od osady. Jest to miejsce tylko częściowo zbadane, ale swoimi zabytkami wskazujące na jego ważne znaczenie od co najmniej okresu wpływów rzymskich do epoki wikingów (Arrhenius 1990). Kompleks składa się z dwóch części, większej, Ormknös A i mniejszej, Ormknös B, tworzących jednostkę o ciekawym składzie. W większej części występują trzy duże kopce i jeden mniejszy, zaraz na północ od nich znajdują się trzy kamienne łodzie i jeden niski kopiec z kamienną obstawą; na stoku wzgórza, na południowej stronie, jest małe cmentarzy- 
grave and the piece from grave $\mathrm{Bj} 655$. The latter grave, with the skeleton in a coffin, also contained a pair of oval brooches "of a transitional type between the Vendel period and the Viking Age", with animal decoration, to be considered as a variant of style III in use at the very beginning of the $9^{\text {th }}$ c. (Jansson 1985, pp. 19-21; Arbman 1940, Pl. 58:3-6; idem 1943, pp. 229ff.).

A fire striker pendant was discovered also near Birka, on Helgö island known for its unique finds, a large group of buildings, burial grounds, workshops and cult places, functioning throughout the first millennium (Lundström ed. 1988). It was a fragmentary example from a cremation grave A2 located in cemetery 116 (Androshchuk 2007, p. 160, Fig. 6:12). The decoration of this piece closely parallels a pendant from Birka grave Bj 99. An almost complete fire striker was found in Uppland, in a cremation burial in grave A5 at Valsta, Norrsunda (Andersson 1997, p. 36, Fig. 28).

Norway is the only place in Scandinavia beside Sweden where fire striker pendants have been discovered. Six examples are known and no new finds have augmented the record published by Petersen. Those with any kind of context were dated to the $9^{\text {th }} \mathrm{c}$. (Petersen 1928, pp. 131ff., Figs 145, 146, 147). Two examples have been noted on the southern Baltic coast, at the Danish site of Menzlin on the Peene river (Kleingärtner 2014, p. 442, Pl. 5:4, 5), and in the east, at Janów Pomorski, the ancient emporium of Truso, behind the delta of the Vistula (Jagodziński 2010, pp. 167ff., Figs 259, 261). In both cases, the finds are unique and did not represent local mass production (although this does not need to be true of Truso where the cemeteries still await discovery).

Fire strikers of the discussed type have also been recorded in Finnish territory (Nordman 1924, pp. 116ff.) and in two localities in eastern Europe. One of these is Sarskoe gorodishche (Сарское городище) on Lake Nero, near the Upper Volga, in a region inhabited by the Finno-Ugric Meria people. From the $9^{\text {th }} \mathrm{c}$. on, the stronghold was occupied by Scandinavians, who judging by the discovered artifacts, including the fire striker pendant, must have originated from central Sweden (Duczko 2006, pp. 160ff.; Hedenstierna-Jonson 2001, pp. 68ff., Fig. 4:1). The other locality is next to the village of Shestovica (Шестовица) on the right bank of the Desna river, $15 \mathrm{~km}$ from Chernikhov in Ukraine. In the $10^{\text {th }} \mathrm{c}$. it was a stronghold and village inhabited by Scandinavians with their families as attested by a rich assemblage of finds and burials (Duczko 2006, p. 201, Figs 71-76). The circumstances of the discovery of the fire striker pendant from Shestovica are not known; it was presented on a photo image imploded on the Internet, together with a few other fire strikers presumably discovered in eastern Europe.

One should consider where such fire striker pendants could have been produced. The idea could have come from the fittings of leather belt endings or horse harness, as exemplified by finds from grave 110 in the cemetery at Ihre, Hellevi on Gotland, dated to the early $1^{\text {st }}$ half of the $10^{\text {th }}$ c. (Stenberger [1961] 1962, p. 44, Fig. 43); an almost identical ending and square fittings with animal decoration come from a grave in Norwegian Borre. In view of the openwork form of the decoration of the fire striker pendant in question, one could also consider openwork bronze endings of leather thongs, which are of similar shape and decorated with animal motifs, 

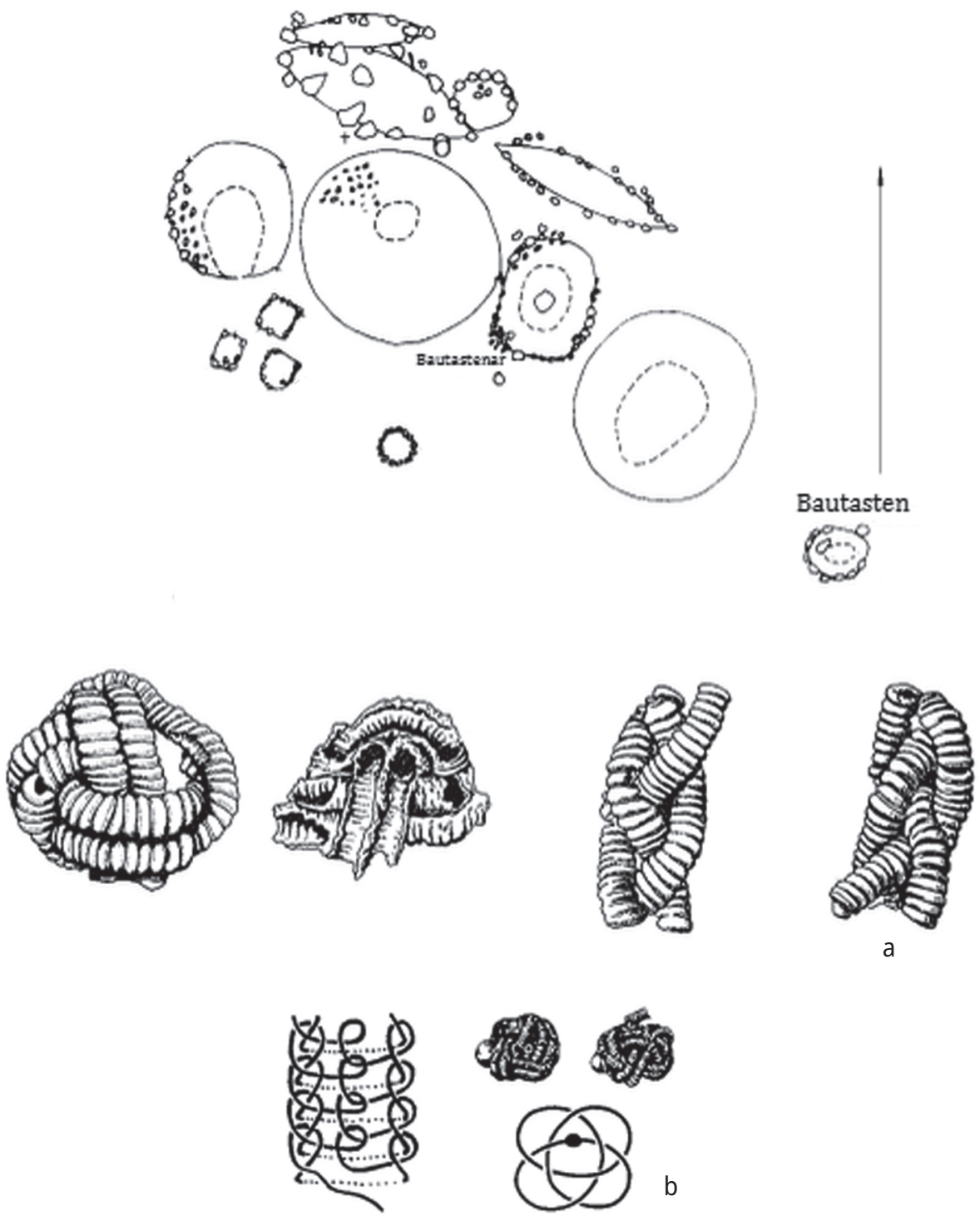

Ryc. 8. Björkö, Szwecja, plan kompleksu Ormknös niedaleko od emporium Birki

W środku - supły i fragment posamentu z Ormknös; na dole - supły posamentowe ze Świelubia (bez skali). Wg Arrhenius i in. 1978, ryc. 1, 4, 11 (a); Zoll-Adamikowej 1980, ryc. 5 (b)

Fig. 8. Björkö, Sweden, map of the Ormknös complex near the Birka emporium

Posament knots and braided fragment from Ormknös in the center; posament knots/braiding? from Świelubie at the bottom (no scale).

After Arrhenius et al. 1978, Fig. 1, 4, 11 (a); Zoll-Adamikowa 1980, Fig. 5 (b) 
and were found in an unknown locality on Gotland, as well as openwork pendants similar in form to the fire striker that were commonplace on Gotland in the $9^{\text {th }} \mathrm{c}$. (Thunmark-Nylén 1998, Pls 167, 266).

While taking into consideration Gotland influence on the production of fire striker pendants, one has to note their absence from typical Gotland accessory sets. By the same, central Sweden must be accepted as the region where objects of this kind were not only used, but also crafted.

\section{POSAMENT}

Next to be considered are ornaments of specific appearance and special function, made in the posament technique (from the French for "braided cording") applied extensively to the ornaments of Scandinavian dress in the Viking Age. Swedish archaeologist Inga Hägg (1983) proposed to connect thin form of ornamentation with a luxury Eastern dress style, primarily of Byzantine origin, indicating the high social status of the wearer. This view was accepted for a long time until progressing textile studies demonstrated its deficiencies. For instance, posament braided knots discovered in inhumation burials seemed to be connected with bags rather than robes and an investigation into production techniques revealed that the silver wire used to make these knots was drawn instead of being cut from thin metal sheets. This observation was important from a technological point of view, because the technique is common to Sweden, while being completely unknown in products from Byzantium (Larsson 2007, pp. 69ff.).

Two posament knots were discovered at Świelubie (Fig. 8, bottom; Łosiński 1974, Fig. 5; Zoll-Adamikowa 1980, Fig. 5). Similar knots were found in 20 Birka graves (male burials, only exceptionally female), and in boat burial No. 12 from the $2^{\text {nd }}$ half of the $10^{\text {th }} \mathrm{c}$. uncovered at the great cemetery of Valsgärde in central Uppland, where only males were buried in boats, as well as in Old Uppsala in a feature of uncertain grave provenance (Larsson 2007, pp. 80ff., Fig. 5). Outside of central Sweden posament knots have also been recorded in a boat burial at Ladby on Funen island and in the richest of the chamber graves (5/1964) at Hedeby, the largest Danish emporium, both these graves dating to the later part of the $1^{\text {st }}$ half of the $9^{\text {th }}$ c. (Larsson 2007, pp. 9ff., 94ff.).

The graves with posament knots from the Birka cemetery represented elite burials for the most part dated to the $10^{\text {th }} \mathrm{c}$. (the $1^{\text {st }}$ half). Discoveries made at another of the Birka cemeteries, which is part of the Ormknös complex, have yielded an earlier date. The complex lies on a hill (Fig. 8, top), approximately $800 \mathrm{~m}$ east of an embankment separating the large cemetery at Hemlanden from the settlement. The site has not been fully excavated, but the artifacts found there already point to its importance from at least the Roman Influences period through the Viking Age (Arrhenius 1990). It is made up of two parts, the larger Ormknös A and the smaller Ormknös B, forming an interesting unit. Three large barrows and one smaller appear in the larger part and directly north of them are three stone boats and a low mound with stone cas- 
sko składające się z czterech grobów otoczonych kamieniami; w dwóch miejscach ustawione są stojące tzw. bautastenar, wysokie kamienie należące do starszej epoki żelaza (Arrhenius i in. 1978, ryc. 1). To tutaj, na cmentarzysku na stoku, w ciałopalnym grobie 1:A, znaleziono dwa supły posamentowe i fragment arabskiego dirhema z 811/812 r. (ryc. 8, pośrodku; Arrhenius i in. 1978, s. 9-15, ryc. 4a, b oraz s. 53).

Część mniejsza kompleksu leży około $200 \mathrm{~m}$ na północ od poprzedniej i składa się z jednego pierścienia o średnicy ponad $10 \mathrm{~m}$, zbudowanego $\mathrm{z} 26$ stojących kamieni, jednego mniejszego pierścienia oraz pięciu niskich, kamiennych kopców (Arrhenius i in. 1978; Holmqvist Olausson 1993, s. 49-53). Trzy kopce zostały zbadane, dwa z nich okazały się być ciałopalnymi, zaś jeden szkieletowym. Najbogatszy był grób ciałopalny A2, w którym pochowano szczątki mężczyzny z koniem i częścią uprzęży, z owcą i kurami, oraz cztery gliniane naczynia, z których dwa były miejscowej produkcji, natomiast pozostałe zachodniosłowiańskiego pochodzenia typu Feldberg i Fressendorf; w grobie znajdowały się również dwa szklane paciorki i trzy fragmenty zachodnioeuropejskiego Trichterbecher, Arwidsson typ 1 (Arwidsson 1984, s. 204). Grób jest datowany na początek IX w.

Kompleks zabytkowy Ormknös nie został systematycznie zbadany, ponieważ nie uznano go za specjalnie istotny element osadnictwa wyspy. Niezrozumienie wartości źródłowej tego stanowiska jest zadziwiające. Pomimo klasycznego zbioru grobowych monumentów - trzech dużych kopców, kamiennych łodzi, kręgów kamiennych, oraz znalezisk nawiązujących do przedmiotów występujących w pochówkach elit, a także długiej ciągłości użytkowania miejsca, i w końcu lokalizacji na wzniesieniu, Ormknös został uznany za ciekawostkę, a nie ważny element wczesnej historii Birki.

O tym, że posamentowe elementy typu świelubskiego były częścią decorum elit skandynawskich, a konkretnie szwedzkich, świadczy jeszcze jedno miejsce, gdzie zostały one odkryte. Supeł pojawił się w grobie 9, datowanym na IX w. (Arhennius i in. 1978, s. 52), na cmentarzysku w Hovgården na wyspie Adelsö, leżącej naprzeciwko wyspy Björkö (Rydh 1936, s. 79, ryc. 197; Brunstedt 1996). To tutaj znajdowała się rezydencja królów kontrolujących emporium Birki. Nazwa - Hovgården - należy do nazw nadawanych miejscom, gdzie zlokalizowane były ośrodki kultu pogańskiego, a które, przynajmniej te większe, były pod opieką królów (Olsen 1966). Ośrodek na Adelsö musiał mieć związek ze szwedzką rodziną królewską, o czym świadczy obecność trzech wielkich kopców, które stanowią kopię pochodzących z VI i początku VII w. trzech kopców w najsławniejszym centrum kultowym Szwedów w Starej Uppsali (Duczko 1997). Obok trzech kopców w Hovgården znajdowało się cmentarzysko, gdzie w jednym z grobów znaleziono posamentowy supeł typu Świelubie. Tu, jak i w Birce, mamy pozostałości po członkach władzy, którzy swoimi strojami i ozdobami, oraz obrządkiem pogrzebowym przekazywali informację o swoim wysokim statusie.

\section{PIONKI}

Gry planszowe były w epoce wikingów niezwykle popularne. Znano je już w okresach lateńskim i rzymskim, skąd gry typu duodecim scripta zostały przejęte 
ing; a small cemetery of four stone-lined graves is situated on the hill slope to the south; so-called bautastenar or tall stones from the older Iron Age stand in two places (Arrhenius et al. 1978, Fig. 1). It is in this cemetery on the slope, in cremation burial 1:A, that two posament knots were found together with a fragment of an Arab dirham from 811/812 (Fig. 8, center; Arrhenius et al. 1978, pp. 9-15, Fig. 4a, b and p. 53).

The smaller part of the complex is situated about $200 \mathrm{~m}$ north of the first part and is made up of a ring of 26 standing stones, its diameter measuring more than $10 \mathrm{~m}$, as well as a smaller ring and five low stone mounds (Arrhenius et al. 1978; Holmqvist Olausson 1993, pp. 49-53). Three of the barrows have been excavated; two proved to be cremation burials, the third was an inhumation. Cremation burial A2 proved to be the richest, the remains of man being buried in it together with a horse and parts of the harness, a sheep and chickens, as well as four clay pots. Two of the pottery vessels were of local make, while the other two were of Western Slavic Feldberg and Fressendorf types; the grave also yielded two glass beads and three fragments of western European Trichterbecher (funnel beakers) identified as Arwidsson type 1 (Arwidsson 1984, p. 204). The grave was dated to the early $9^{\text {th }} \mathrm{C}$.

The Ormknös complex was not considered as a particularly important site on the island, hence the limited nature of the investigations that were carried out here. This lack of interest drawing from a lack of awareness of the source value of this site is astounding. It was considered as a curiosity rather than an important component of early Birka history and this despite a classic set of grave monuments comprising three large barrows, stone boats and artifacts associated with elite burials, not to mention the long tradition of unbroken settlement on the hill.

There is one other place where posament elements of the Świelubie type were discovered, testifying to their role parts of the decorum of Scandinavian and specifically Swedish elites. It is grave 9 from the $9^{\text {th }}$ c. (Arhennius et al. 1978, p. 52) from the cemetery at Hovgården on Adelsö island, situated opposite Björkö island (Rydh 1936, p. 79, Fig. 197; Brunstedt 1996). The residence of the kings controlling the Birka emporium was located here. The name of Hovgården is a place name for pagan cult centers, which were, at least the larger ones, in the kings' protection (Olsen 1966). The cult place on Adelsö must have been connected with the Swedish royal family as indicated by three large barrows which are a copy of the three large barrows from the $6^{\text {th }}$ and early $7^{\text {th }} \mathrm{c}$. in the most famous cult place of the Swedes in Old Uppsala (Duczko 1997). The grave which yielded a posament knot of the Świelubie type was part of a cemetery that lay next to the three barrows at Hovgarden. Like in Birka, we are dealing here with the remains of members of the ruling class who would have passed information on their high social status through their dress and ornaments as well as burial rites.

\section{GAME COUNTERS}

Board games were extremely popular in Viking times. They were already known in the La Tène and Roman periods, the Germanic tribes, including the Scandina- 
przez ludy germańskie, włącznie ze skandynawskimi (Petersen 1914; Murray 1952, s. 55 nn.; Hall 2016). Dostarczanie rozrywki nie było wyłączną funkcją gier planszowych. Jak to było z większością kulturowych zajęć, funkcja religijno-magiczna była tu nawet ważniejsza od funkcji zabawowej (Duczko 2016a; 2016c). Dobrze przedstawił to Jacek Banaszkiewicz w swoim artykule o Herulach, ludzie pochodzącym ze Skandynawii, i ich królu, który w trakcie bitwy siedział w namiocie i grał o zwycięstwo z losem (Banaszkiewicz 2018).

Archeologia dostarczyła wielu dowodów na popularność gier planszowych. Liczba znajdowanych pionków jest imponująca. Już w roku 1914 J. Petersenowi było znanych z wikińskiej Norwegii 329 pionków z 46 grobów. Uporządkował je w trzy typy - A, B, C - jednocześnie określając materiał, z którego były wykonane (kość, glina, szkło i bursztyn) oraz technologię ich wytwarzania (Petersen 1914, s. 86). Na nadal w małym stopniu zbadanej osadzie emporium Truso w Janowie Pomorskim z ogółu 42 odkrytych egzemplarzy, bursztynowych było 28 (Jagodziński 2015, s. 77-84).

$\mathrm{Na}$ cmentarzyskach Birki pionki wystąpiły w 17 grobach (Arbman 1940, tabl. 147-150). W czterech mamy zestawy szklanych pionków, $\mathrm{w}$ jednym $\mathrm{z}$ bursztynu, w pozostałych $\mathrm{z}$ kości. Niektóre groby zawierały nie tylko dużą liczbę pionków, ale nawet plansze, na przykład w grobach komorowych będących pochówkami inhumacyjnymi uzbrojonych mężczyzn: Bj 624 (27 pionków), Bj 886 (25), Bj 581 (28). Co do tego ostatniego grobu, uznanego po badaniu DNA za pochówek kobiety, trzeba podkreślić, że nie jest to poprawna identyfikacja! Szerzej kwestia ta zostanie omówiona przy innej okazji. Jest tu jednak także kilka męskich grobów ciałopalnych zawierających dużą liczbę pionków: Bj 20 (35), Bj 821 (20). Ten ostatni grób jest najstarszym wśród grobów z grami planszowymi, mianowicie z IX w., o czym świadczy ceramika oraz fragmenty typowego dla tego stulecia szklanego pucharu typu Trichterbecher (Arbman 1943, s. 34 nn., ryc. 24).

W grobach odkrywa się także pojedyncze pionki, co może oznaczać, że mogły one mieć jakieś symboliczne znaczenie, na tej samej zasadzie, jak trzymanie pojedynczych ciężarków wagowych w torebkach razem $\mathrm{z}$ różnymi przedmiotami. $\mathrm{O}$ tym, że pionki były istotne dla Skandynawów, świadczy ich liczna obecność - 71 sztuk na ciałach zabitych w bitwie ponad trzydziestu Szwedów pochowanych w łodzi w Salme, na estońskiej wyspie Saaremaa. Wydarzenie datowane jest na przełom VII i VIII w., czyli na sam początek epoki wikingów (Peets i in. 2010).

Pionki używane do gier planszowych, zwłaszcza tej najpopularniejszej - Hnefatafl (Adamczyk 2011), miały standardowe formy, zwykle kuliste. Do innych gier używano płaskich, okrągłych krążków, czasami z otworem pośrodku (Bjarnason [1911-1913] 1913). Trzy pionki pierwszego typu odkryto w świelubskim grobie I (patrz ryc. 4e; Żak 1963, s. 281, ryc. 67:5a-c), pionek krążkowy zrobiony z rogu pojawił się w grobie 24 (ryc. 5, na dole po prawej; Łosiński 1972, s. 25, ryc. 101f).

Wiedza o grach jest niezbędna, gdyż musimy zrozumieć, jak ważne dla Skandynawów były gry planszowe. Dzięki temu jesteśmy w stanie uznać znaleziska pionków, nawet pojedynczych, za ważne świadectwo obecności ludzi z Północy w miejscu odkrycia. 
vians, inheriting games of the duodecim scripta type (Petersen 1914; Murray 1952, pp. 55ff.; Hall 2016). Entertainment was not the only function. Like with most cultural activities, the religious and magic functions were often more important (Duczko 2016a; 2016c). Jacek Banaszkiewicz has given a good presentation of this in his article on the Heruli, a people allegedly from Scandinavia, and their king who sat in his tent during a battle, playing with fate for victory (Banaszkiewicz 2018).

The body of archaeological data attesting the popularity of board games is extensive. Impressive numbers of game counters have been found. In 1914, Petersen counted 329 game counters from 46 graves from Viking Norway, and classified them in three types $(\mathrm{A}, \mathrm{B}, \mathrm{C})$, at the same time determining the material from which they were made (bone, clay, glass and amber) and the technique of execution (Petersen 1914, p. 86). From the still little excavated settlement of emporium in Truso in Janów Pomorski, 28 of the 42 game counters discovered there were made of amber (Jagodziński 2015, pp. 77-84).

At the Birka cemetery, game counters were found in 17 graves (Arbman 1940, Pls 147-150). Four graves yielded sets of glass counters, one an amber counter and the rest bone counters. Some of the graves even had the game boards together with the counters, e.g., the chamber tombs with inhumation burials of warriors: Bj 624 (27 counters), Bj 886 (25), Bj 581 (28). With regard to the last of the listed graves, which has been determined as a female burial following aDNA analysis, it should be emphasized that the identification is not correct! (it will be discussed in more detail elsewhere). However, there are several other male burials with large sets of game counters, i.e., $\mathrm{Bj} 20$ (35) and $\mathrm{Bj} 821$ (20). The latter grave is the oldest among those with evidence of board gams, being dated to the $9^{\text {th }} \mathrm{c}$. on the grounds of the pottery material as well as the glass funnel beakers (Trichterbecher) typical of the age (Arbman 1943, pp. 34ff., Fig. 24).

Single game counter in graves could mean that the objects had some symbolic significance, just as single balance weights were kept in pouches with other objects to bring luck. Their significance for the Scandinavians is demonstrated by their numbers, altogether 71 pieces, found on the bodies of the 30 Swedes killed in battle and buried in a boat in Salme on the Estonian island of Saaremaa. The event is dated to the end of the $7^{\text {th }}$ or beginning of the $8^{\text {th }} \mathrm{C}$., that is, the very dawn of the Viking Age (Peets et al. 2010).

Game counters were used for board games, especially the most popular one called Hnefatafl (Adamczyk 2011), and they were usually of a standard spheroid form. The shape was different for other games: flat circular disks, sometimes pierced (Bjarnason [1911-1913] 1913). Three game counter of the first type were discovered in Świelubie grave I (see Fig. 4e; Żak 1963, p. 281, Fig. 67:5a-c), a discoid game counter made of horn was found in grave 24 (Fig. 5, bottom right; Łosiński 1972, p. 25, Fig. 101f).

Understanding how important board games were to the Scandinavians leads to the conclusion that even single finds of counters in a given locality constitute important evidence for the presence of people from the North at the place of discovery. 


\section{CIĘŻARKI WAGOWE}

W epoce wikingów srebro było głównym miernikiem wartości. Dzięki religijno-magicznemu zwyczajowi chowania w ziemi monet, ozdób, sztabek i innych całych lub fragmentarycznych przedmiotów w formie depozytów-skarbów, zachowała się duża ilość srebra, dając nam dostęp do różnorodnego materiału źródłowego pozwalającego na studiowanie ekonomii, sztuki i relacji społeczno-gospodarczych (Duczko 2005; Adamczyk 2018). Na obszarach Europy, gdzie posługiwanie się pieniądzem w systemie monetarnym nie było praktykowane, srebro było ważone, do czego używano składanych wag z kompletami ciężarków. Takie zestawy odkrywane są w Skandynawii oraz tam, gdzie działała sieć handlu kontrolowana przez Skandynawów, czyli w Europie Wschodniej i w basenie Morza Bałtyckiego. Przykładem znalezisk są przedmioty z Janowa Pomorskiego, z osady emporium Truso. W trakcie wykopalisk prowadzonych od roku 1984 dokonano odkryć 16 wag składanych i 369 ciężarków różnego typu (Steuer 2012, s. 186, ryc. 6.1, s. 189 nn., ryc. 6.3, 4). W obrębie osady w Birce, w trakcie wykopalisk prowadzonych w latach 19701971 natrafiono natomiast na ponad 300 ciężarków, wśród których było 30 ciężarków kubooktaedrycznych (ośmiostronnych) i 150 okrągłych spłaszczonych (Kyhlberg 1973; Sperber 1996, s. 80-85).

Ciężarki wagowe były niezbędnym elementem w prowadzeniu handlu, a ponieważ ten zawsze był działalnością pełną niebezpieczeństw, nie tylko utraty towaru, ale i życia, nie wspominając o możliwości bycia oszukanym, to, jak wszystkie aspekty życia, wymagał zwracania się o pomoc do sił nadprzyrodzonych. Jednym ze sposobów uniknięcia oszustwa było nacinanie srebra. Pozwalało ono stwierdzić, czy dany przedmiot $\mathrm{w}$ całości zrobiono $\mathrm{z}$ tego metalu. Czynność ta przekształciła się w magiczny rytuał praktykowany w trakcie transakcji (Duczko 2002). Innym sposobem zapewnienia sobie szczęścia w interesach było noszenie pojedynczego ciężarka wagowego jako magicznego amuletu.

Ciężarek z brązu „w kształcie dwustronnie spłaszczonej kuli” odkryto na grodzisku w Bardach (Łosiński 1972, s. 250, ryc. 93g). Na cmentarzysku świelubskim, w ciałopalnym grobie 14, ciężarek powyższego typu znaleziono wśród blaszek z brązu i kilkudziesięciu przedmiotów żelaznych (Łosiński 1972, s. 264-265). W grobie 21 był jeden mały, kubooktaedryczny ciężarek z brązu, na którego każdej ze stron stwierdzono obecność podwójnych linii składających się z trzech punktów; podobny wystąpił w częściowo rozkopanym ciałopalnym grobie 8, w którym znaleziono też fragment dirhemu z 780-850 r. (Łosiński 1972, s. 249, ryc. 99e oraz s. 262-263).

\section{TARCZE}

Do tej pory zajmowaliśmy się przede wszystkim przedmiotami związanymi z kobietami, a to, czego nam brakowało, to mężczyzn z bronią. Podczas gdy z łatwością stwierdzamy obecność kobiet z ich ozdobami, grobów z mieczami, nożami 


\section{BALANCE WEIGHTS}

During the Viking period silver was the main measure of value. The religious and magical custom of collecting coins, ornaments, ingots and other whole and fragmentary objects in hoards concealed underground has resulted in a large amount of silver being preserved. This gives modern researchers the opportunity to study the economy, art and social relations of ancient societies (Duczko 2005; Adamczyk 2018). In Europe, where monetary systems were not practiced, silver was weighed using special balances with complete sets of weights. Sets of this kind have been discovered in Scandinavia and wherever Scandinavian trade reached, that is, in eastern Europe and the Baltic region. Examples come from the ancient emporium of Truso, modern Janów Pomorski, where excavations conducted since 1984 have uncovered 16 folding balances and 369 weights of different type (Steuer 2012, p. 186, Fig. 6.1, pp. 189ff., Fig. 6.3, 4). Excavations at Birka in 1970-1971 uncovered more than 300 balance weights, including 30 cubo-octahedral ones and 150 oblate spheroids (Kyhlberg 1973; Sperber 1996, pp. 80-85).

Balance weights were essential in trade, which being an occupation fraught with danger - not only because of the threat of losing the goods, but also because of fear for one's life, not to mention the fear of being cheated - demanded (like many other aspects of human life) that people look to the supernatural for assistance. One way of avoiding being cheated was to cut silver to see whether it was made of solid metal. This became a magic ritual practiced during commercial transactions (Duczko 2002). Another way of ensuring luck was to carry a single balance weight as a magical amulet.

A balance weight of bronze in the shape of an oblate spheroid was discovered at the stronghold of Bardy (Łosiński 1972, p. 250, Fig. 93g). A weight of this kind was found among the bronze sheet metal and a few dozen iron artifacts in a cremation burial in grave 14 at the Świelubie cemetery (Łosiński 1972, pp. 264-265). Grave 21 yielded a small cubo-octahedral bronze weight signed on all sides with a double set of three points within a square; a similar weight was discovered in a partly excavated cremation burial in grave 8 , which also yielded a cut dirham from 780-850 (Łosiński 1972, p. 249, Fig. 99e and pp. 262-263).

\section{SHIELDS}

All of the artifacts presented so far are associated with women. Missing are the men with weapons. The presence of women with their ornamental accessories is easily noted, but graves with swords, combat knives, spears and arrowheads are simply not there. Remains of dead warriors in the Świelubie graves are represented by the metal parts of shields: the cast bronze fittings of a central handle, rectangular iron sheet fittings and one boss. These objects were discovered in graves 3 and 6, and the boss in cremation burial 12/15/17 (Łosiński 2000, pp. 73ff.; Rudziński 2009, pp. 46-48, Fig. 5). The first discoveries made in 1964 were described by Łosiński as "a very interesting set of artifacts [...] presumably of Scandinavian origin" (Łosiński 
bojowymi, ostrzami włóczni czy strzał, nie mamy. Ale ślady po zmarłych wojownikach pozostały i znajdują się w grobach świelubskich, a są to metalowe części tarczy przedstawiające dekoracyjne okucia $\mathrm{z}$ brązu przy imaczu, prostokątne obicia z żelaznej blachy a nawet jedno umbo. Takie elementy odkryto w grobach nry 3 i 6 , oraz umbo w grobie ciałopalnym 12/15/17 (Łosiński 2000, s. 73 nn.; Rudziński 2009, s. 46-48, ryc. 5). W pierwszym z nich, zbadanym w roku 1964, znaleziono przedmioty uznane przez odkrywcę za „...dość interesujący zestaw zabytków [...], zapewne pochodzenia skandynawskiego" (Łosiński 1966, s. 167-168, ryc. 4). Powściągliwość nie była tu potrzebna. Sam badacz stwierdził obecność prawie identycznego fragmentu odlanego w brązie okucia imacza z twarzą ludzką w komorowym grobie Bj 467b w Birce, a okucia tarczy z żelaznej blachy w grobie Bj 369 (ryc. 9; Arbman 1943, s. 134-135; tenże 1940, tabl. 18:3, 19:5; o tarczach z Birki patrz Arwidsson 1986; por. Łosiński 1972, s. 247, ryc. 99c).

Brązowe okucie z twarzą mężczyzny z wąsami i okrągłymi oczami ma kształt krzyża z krótkimi ramionami i niewiadomej długości dolną częścią, najczęściej odłamaną. Jest to jeden z dwóch typów tego rodzaju okuć. Drugi typ, najpopularniejszy, pojawił się w świelubskim grobie 6: forma litery T do góry nogami, na górze długiej części jest ludzka twarz bez wąsów i z owalnymi oczami; dolna, rozwidlona część, ma półokrągłe zakończenia.

Okucie imacza typu pierwszego ze Świelubia i okucie z grobu Bj 467b z Birki sprawiają wrażenie, jakby były wykonane ręką tego samego artysty. Jest jeszcze jeden egzemplarz, bardzo do nich podobny, z Riurikowego gorodiszcza (Рюриково городище) koło Nowogrodu. Ten okaz ma cechy typu pierwszego, z jednym wyjątkiem: oczy są owalne. Ta sama mieszanka jest obecna na okuciu z Gotlandii znalezionym bez kontekstu (Thunmark-Nylén 1998, tabl. 263:7; taż 2006b, s. 318-319). Typ drugi jest najbogaciej reprezentowany przez znaleziska z Birki (Bj 42, 850, 944, 1151), włącznie z miejscem zwanym Garnizonem (Garnisonen), przy forcie Birki (Stjerna 2001, ryc. 7:1), ale występuje także niedaleko Sztokholmu, gdzie na cmentarzysku w Tureberg Gård, Sollentuna, Uppland w grobie A 33b odsłonięto dwa egzemplarze takiego okucia. Blisko Birki, na Helgö, w grobie A 37 na cmentarzysku 116 pojawiło się natomiast okucie będące wariantem obu znanych nam typów (Arbman 1940, tabl. 19:1-4, 7; Nilsson 1972, s. 57, ryc. 40; Androshchuk 2007, s. 160, ryc. 6:6). Odkryta na terenie osady w Birce forma do odlewu podobnych okuć pokazuje, że produkcja odbywała się na miejscu, i jak się uważa, w najmłodszej fazie istnienia Birki, czyli w 1 poł. X w. (Ambrosiani, Erikson 1996, s. 11).

Częstość występowania okuć do imaczy w Birce jest czymś wyjątkowym w Skandynawii i wskazuje na środkową Szwecję jako miejsce ich wytwarzania. Pojedyncze egzemplarze znajdowane poza Szwecją są świadectwem związku ich użytkowników ze szwedzkimi elitami władzy, a nawet obecności Szwedów, tak, jak to było od około 860 r. nad rzeką Wołchow, w miejscu obecnie nazywanym Riurikowo gorodiszcze, pierwotnie być może Hólmr, a w połowie $\mathrm{X}$ w. wedle bizantyjskiego przekazu Nemogardas (Duczko 2004, s. 99 nn.; tenże 2006, s. 87). Tu znajdowało się centrum władzy Rusów, grupy, która pod koniec IX w. osiadła nad środkowym Dnie- 

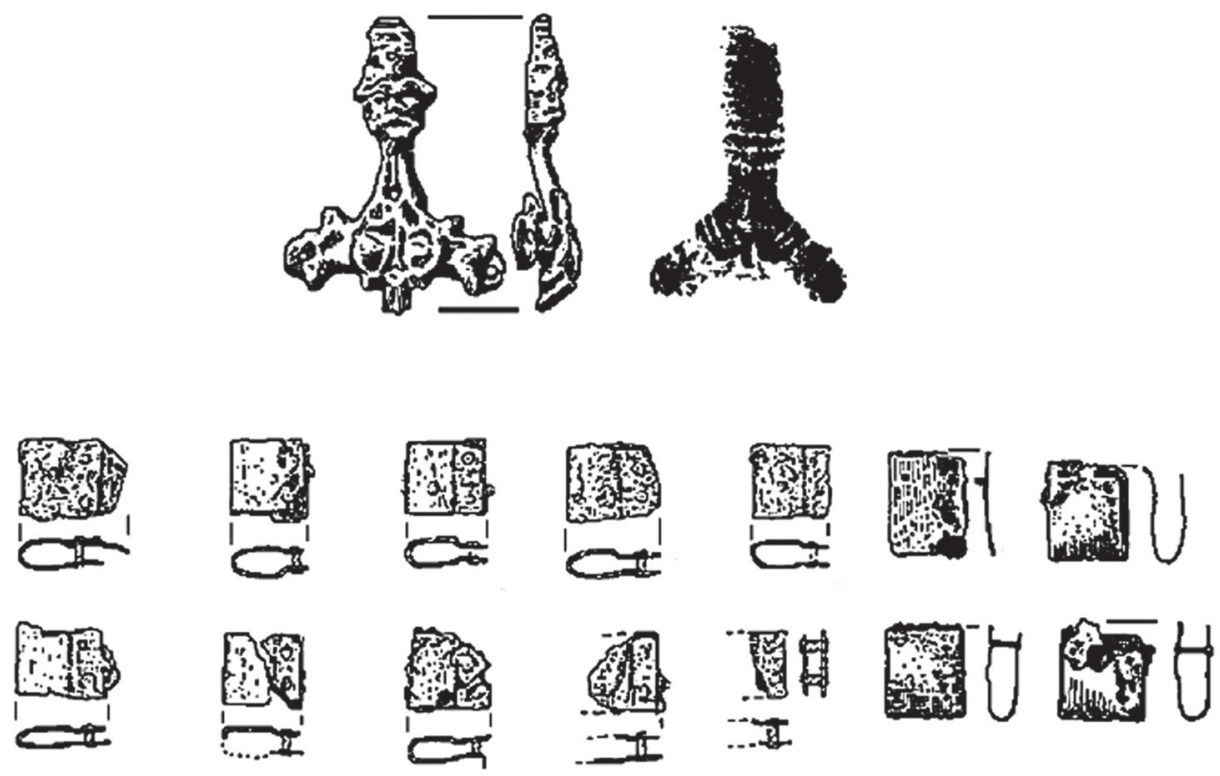

Ryc. 9. Świelubie, okucia tarcz.

Wg Rudzińskiego 2009, ryc. 5

Fig. 9. Świelubie, shield fittings.

After Rudziński 2009, Fig. 5

1966, pp. 167-168, Fig. 4). His reticence was not justified as he himself noted an almost identical fragment of a handle fitting cast in bronze and decorated with a human face, coming from a chamber tomb Bj $467 \mathrm{~b}$ at Birka, as well as iron sheet fittings from grave Bj 369 (Fig. 9; Arbman 1943, pp. 134-135; idem 1940, Pls 18:3, 19:5; on the shields from Birka, see Arwidsson 1986; cf. Łosiński 1972, p. 247, Fig. 99c).

The bronze fitting with decoration in the form of the countenance of a roundeyed moustached male is of cruciform shape with short cross-arms and the lower arm of unknown length (it is broken as a rule), typifying one of the two kinds known. The other type, which is the most popular one, surfaced in grave 6 at Świelubie: an upside-down T-shaped fitting with a human face without moustache and with oval eyes; the lower part of the fitting is forked and is semicircular in shape.

The handle fittings of the first type from Świelubie and the fitting from grave Bj 467b at Birka look as if made by the hand of the same craftsman. A very similar piece comes from the hillfort Riurikovo Gorodishche near Novgorod with one exception: the eyes are oval instead of being round. The same combination of characteristic features appears on a Gotland fitting found outside of any context (Thunmark-Nylén 1998, Pl. 263:7; idem 2006b, pp. 318-319). The second type is illustrated 
prem, gdzie stworzyła ośrodek w Kijowie, skąd książę regularnie wysyłał jednego ze swoich synów do Nemogardas, aby na północy pilnował interesów grupy. Zabytki $\mathrm{z}$ tego miejsca mają odpowiedniki w materiale w Birce (Duczko 2004, s. $104 \mathrm{nn}$., ryc. 25-28; tenże 2006, ryc. 25-28), co tłumaczy, skąd się tu wzięło okucie do imacza podobne do tego ze Świelubia.

Na koniec musimy zaznajomić się z jeszcze jednym egzemplarzem okucia uchwytu tarczy, który pojawił się w wyjątkowym co do formy i wyposażenia grobie, nieopodal wielkiego emporium Hedeby, ongiś w Danii, obecnie w Niemczech. Grób ten to słynny Bootkammergrab składający się z komory z pochówkami, a nad nią postawionego wikińskiego statku (Müller-Wille 1976, ryc. 13; Wamers 1994, ryc. 3 i 4). Komora była podzielona na dwie części, w lewej, mniejszej (Kammer B) złożono jedną osobę, w prawej, większej (Kammer A), dwie. Szczątki zmarłych nie zachowały się, natomiast przetrwały metalowe przedmioty ukazujące status pochowanych: w lewej części znajdował się wyjątkowej jakości karoliński miecz, dwa umba i jedno okucie imacza typu drugiego (Wamers 1994, ryc. 22.3), ostrogi, srebrne zawieszki $z$ dekoracją filigranową, insularne naczynie z brązu, grzebień, część uprzęży końskiej i szklany Trichterbecher. W większej części komory były dwa karolińskie miecze, jeden Sondertyp I, drugi typu K według Petersena, oraz dwa umba, nóż i żelazne strzemiona (Müller-Wille 1976, s. $45 \mathrm{nn}$.).

Grób odkryto w roku 1908 i od tej pory toczyły się na jego temat dyskusje. Badaczy interesowało przede wszystkim określenie czasu powstania grobu i ustalenie, która $\mathrm{z}$ historycznych duńskich postaci została w nim pogrzebana. Monumentalność grobu i jakość złożonych w nim przedmiotów miały świadczyć, jak uważano, o pochówku króla razem z dwoma wojownikami. Datowanie grobu na przełom IX i X w. przez Michaela Müller-Willego (Müller-Wille 1976, s. 140 nn.) odsunęło na bok wcześniejsze - na połowę IX w. (m.in. Arbman 1937, s. 225), i pozwoliło niektórym duńskim historykom (np. Andersen 1987, s. $171 \mathrm{nn}$.) uznać głównego z pochowanych za Olafa, szwedzkiego władcę Hedeby, który zapoczątkował dynastię rządzącą emporium do lat czterdziestych X w. Powrót do poprzednio uznawanego datowania podjął Egon Wamers, stwierdzając, że pochówek w Bootkammergrab jest pochówkiem jednego z królów duńskich, najprawdopodobniej Haralda Klaka (Wamers 1994). Trudno w tym miejscu odnieść się szerzej do problemu, kto miał rację, mogę tylko stwierdzić, że związek tego grobu ze szwedzką dynastią wydaje mi się bardziej zgodny z jego datowaniem na późny IX w.

Powróćmy teraz do okuć i grobów z Birki, by ustalić ich chronologię i kontekst historyczny.

Wśród siedmiu wyżej wspomnianych grobów w Birce pięć to groby komorowe. Najlepiej zachowany, i najbogaciej wyposażony, to Bj 944. Jest to pochówek mężczyzny z mieczem i nożem bojowym, tzw. saksem, ostrzem włóczni, umbem tarczy, czterema żelaznymi ostrogami, grzebieniem, zapinką do płaszcza, naramiennikiem, resztkami ekskluzywnego stroju, jednym ciężarkiem wagowym, różnymi żelaznymi przedmiotami oraz grzebieniem z kości dla konia. Koń zmarłego został złożony na 
with the most finds at Birka (graves Bj 42, 850, 944, 1151), including a spot called a Garrison (Garnisonen) next to the Birka fort (Stjerna 2001, Fig. 7:1), but it is also present at the cemetery of Tureberg Gård, Sollentuna, Uppland near Stockholm, where two such fittings were discovered in grave A 33b. At Helgö near Birka, grave A 37 in cemetery 116 yielded a fitting that turned out to be a variant combining the two known types (Arbman 1940, Pl. 19:1-4, 7; Nilsson 1972, p. 57, Fig. 40; Androshchuk 2007, p. 160, Fig. 6:6). A casting mold for similar fittings discovered in the Birka settlement indicates production on the spot, dated most probably to the youngers Birka phase in the $1^{\text {st }}$ half of the $10^{\text {th }}$ c. (Ambrosiani, Erikson 1996, p. 11).

The high frequency of fittings found in Birka is exceptional in Scandinavia and points to central Sweden as the place of production. Single examples found outside Sweden are proof of the ties between their users and Swedish ruling elites. It may even corroborate the presence of Swedes in a given place, as for instance, at the locality called Rurik's hillfort (Riurikovo Gorodishche) on the Volkhov river around 860 (Duczko 2004, p. 99ff.; idem 2006, p. 87). This site, which was possibly called Hólmr at first and was referred to as Nemogardas in a Byzantine source from the mid-10 $10^{\text {th }}$ c., was a center of Rus' power, controlled by a group of new settlers on the middle Dnieper, who established themselves at Kiev in the late $9^{\text {th }} \mathrm{c}$. and whose prince regularly sent one of his sons to Nemogardas to control the group's interests in the north. Artifacts from this locality find counterparts in the Birka material (Duczko 2004, p. 104ff., Figs 25-28; idem 2006, Figs 25-28), explaining why the handle fitting from this site is so like the specimen from Świelubie.

Last but not least, there is a shield handle fitting from a grave near the great emporium of Hedeby, which was once in Denmark and is now in Germany. This grave has been made famous as the Bootkammergrab. It is exceptional in form a burial chamber with a Viking boat placed above it (Müller-Wille 1976, Fig. 13; Wamers 1994, Figs 3 and 4). The chamber was divided into a smaller unit on the left (Kammer B) for one individual and a larger one on the right (Kammer A) for two burials. The bones were not preserved, but the surviving metal artifacts leave no doubt as to the elite status of the deceased buried in this grave. A Carolingian sword of unmatched quality was found with the individual buried in the left chamber, alongside with two shield bosses and one handle fitting of the second type (Wamers 1994, Fig. 22.3), spurs, silver pendants with filigree decoration, an insular bronze vessel, a comb, components of a horse harness and a glass funnel beaker (Trichterbecher). The larger chamber contained two Carolingian swords (one of the Sondertyp I type, the other a type K according to Petersen) and two shield bosses, a knife and iron spurs (Müller-Wille 1976, pp. 45ff.).

A heated debate has raged around this tomb ever since its discovery in 1908. It has concerned chronology as well as the identity of the deceased, particularly the question of whether they could be linked to any of the historical Danes. The monumentality of the complex and the fineness of the grave furnishings suggested to researchers a king with two of his warriors as the occupants of the grave. Michael Müller-Wille moved the dating of the tomb to the close of the $9^{\text {th }}$ and beginning of the $10^{\text {th }}$ centuries (Müller-Wille 1976, pp. 140ff.) superseding an earlier dat- 
platformie w końcu komory (Arbman 1943, s. 368-371, ryc. 320 i 321). Grób jest podobny do kilku innych tego rodzaju pochówków mężczyzn z uzbrojeniem, jakie pojawiają się głównie na elitarnym cmentarzysku Norr om Borg, oraz niektórych częściach największego cmentarzyska Hemlanden, gdzie znajduje się powyżej opisany grób. Tego rodzaju groby komorowe wojowników są datowane na połowę X w. W należącym do tej serii grobie Bj 834 znaleziono dirhemy, z których najmłodszy miał datę wybicia 925/926 r. (Arbman 1943, s. 305).

Inne groby z okuciami były wcześniejsze. Bj 850 i Bj 942 były wielkimi komorami z ograniczonym wyposażeniem składającym się głównie z jednego miecza i włóczni oraz szklanych pucharów typu Trichterbecher (Arbman 1943, s. 323-325, ryc. 272, Bj 850, s. 364-366, ryc. 315, Bj 942). Miecze były luksusowymi karolińskimi produktami, z których ten z Bj 942, typu Petersen 1, a typu Mannheim według Jankuhna, należał do wczesnego IX w., tak jak ostrze włóczni typu Petersen A, natomiast włócznia z Bj 850 do typu Petersen D (Petersen 1919, s. 22-27; Duczko 1985, s. 104-105).

Zakończmy ten przegląd grobem Bj 1151, który był wielkim grobem komorowym z bronią: mieczem, ostrzem włóczni oraz umbem tarczy i do niej należącymi dwoma okuciami typu drugiego (Arbman 1940, s. 474 nn., ryc. 449). Miecz - typ E lub D Petersena, włócznia - typ E Petersena, są datowane na IX w. (Petersen 1919, s. 26-27, 70 nn.). W grobie znajdowały się także szczątki ekskluzywnego stroju i mieszek, w którym znaleziono dwa abbasydzkie dirhemy z Madinat al-Salam, z datami 757-767 i 767-776 r. W kopcu nad grobem leżał żelazny naszyjnik z zawieszką młota Thora i niespalone kości bydła, co wskazuje na klasyczną ofiarę, typową dla środkowej Szwecji.

Podsumowując tę część artykułu, możemy stwierdzić, że okucia do imacza tarczy pojawiają się w 1 poł. IX w. i wychodzą z użycia po połowie wieku X. Ich koncentracja w środkowej Szwecji w pochówkach elit, przede wszystkim militarnych, wskazuje na pochodzenie zmarłych ze środowiska bliskiego najważniejszej władzy. Formy detali dekoracyjnych tarcz z grobów świelubskich świadczą więc, jak wykazaliśmy wyżej, o ich pochodzeniu ze Szwecji i razem z innymi przedmiotami są dowodem na to, że w skandynawskiej grupie żyjącej w IX w. nad Parsętą byli wojownicy, którzy przybyli ze środkowej Szwecji.

\section{WNIOSKI}

Po prezentacji grobów i znalezionych w nich przedmiotów możemy przejść do sformułowania wniosków. Zacznijmy od cmentarzyska w Świelubiu jako całości. Jego zły stan zachowania oraz ograniczona liczba zbadanych grobów powodują, że nie możemy wypowiadać się na temat granic czasowych, w obrębie których grupa skandynawska mieszkała nad dolną Parsętą. Także sprawa etniczności całości cmentarzyska nie jest możliwa do ustalenia. Próby W. Łosińskiego mające na celu określenie innego niż skandynawskie pochodzenia zmarłych pochowanych w niektórych grobach należy uznać za nie w pełni udane. Częściowo dlatego, że jeżeli cmentarzysko istniało tu tylko w IX w., to Pomorze nadal znajdowało się w obrębie 
ing to the mid $9^{\text {th }}$ c. (i.a., Arbman 1937, p. 225), allowing some Danish historians (e.g. Andersen 1987, pp. 171ff.) to identify the single individual buried in the left chamber as the Swedish ruler of Hedeby Olaf, founder of a dynasty that ruled the emporium until the 940s. Egon Wamers argued in favor of the previous dating of the Bootkammergrab, seeing it as the burial of one of the kings of the Danes, most probably Harald Klak (Wamers 1994). Without going into a discussion of which of these theories is the most correct, I can only say that the links between this tomb and the Swedish dynasty make its dating to the late $9^{\text {th }}$ c. more likely.

Let us turn back, however, to the Birka finds in order to determine the chronology and historical context. Five of the seven tombs from Birka are chamber tombs and $\mathrm{Bj} 944$ is the best preserved and best furnished of these. It holds the burial of a man, who was given an extensive set of weapons: a sword, combat knife (so-called sax), spear, shield boss, four iron spurs, comb, cloak fastening, arm-ring, remains of exclusive robes, one balance weight, a diversity of iron objects and a bone curry comb. The horse of the deceased was laid out on a platform at the end of the chamber (Arbman 1943, pp. 368-371, Figs 320 and 321). The tomb resembles a few other male burials of the kind, furnished with weaponry, that are known chiefly from the elite cemetery of Norr om Borg and a few parts of the largest cemetery at Hemlanden where the above described tomb is located. Chamber tombs for warriors of this kind are dated to the mid- $10^{\text {th }} \mathrm{c}$. Tomb Bj 834 from this series yielded dirhams, the youngest of which were struck in 925/926 (Arbman 1943, p. 305).

Other tombs with fittings were of earlier date. Bj 850 and Bj 942 were huge chambers with rather limited furnishings composed of a sword and spear, to which glass funnel beakers of the Trichterbecher type were added (Arbman 1943, pp. 323-325, Fig. 272, Bj 850, pp. 364-366, Fig. 315, Bj 942). The swords were luxury Carolingian products, the one from $\mathrm{Bj} 942$ representing a Petersen 1 type, which is a Mannheim type according to Jankuhn, dated to the early $9^{\text {th }}$ c., just like a spearhead of the Petersen A type, whereas the spearhead from grave $\mathrm{Bj} 850$ was of the Petersen D type (Petersen 1919, pp. 22-27; Duczko 1985, pp. 104-105). Last but not least in this review is $\mathrm{Bj} 1151$, a huge chamber tomb with weapons among the furnishings: sword, spearhead and shield boss along with two shield fittings of the second type (Arbman 1940, pp. 474ff., Fig. 449). The sword (Petersen's E or D types) and spearhead (Petersen's type E) are both dated to the $9^{\text {th }}$ c. (Petersen 1919, pp. 26-27, 70ff.). The burial also contained remains of exclusive dress and a pouch with two Abbasid dirhams struck for Madinat al-Salam, dated 757-767 and 767-776. The mound above the grave yielded an iron necklace with a Thor hammer pendant and unburned cattle bones, both indicative of a classical grave offering typical of central Sweden.

In recapitulation, shield handle fittings were introduced in the $1^{\text {st }}$ half of the $9^{\text {th }}$ c. and went out of use after the middle of the $10^{\text {th }} \mathrm{c}$. Their concentration in elite, primarily military, burials in central Sweden suggest that the dead were members of the highest ruling class. The ornamental details of the shields from the Swielubie graves point to their Swedish origin, as demonstrated above. Together with the other artifacts from the graves, they are proof that the group of Scandinavians living on the banks of the Parsęta river in the $9^{\text {th }} \mathrm{c}$. were warriors native to central Sweden. 
wieleckiego obszaru kulturowego, gdzie dominował bezgrobowy obrządek pogrzebowy, ponieważ jam typu Alt Käbelich, tak częstych na tym obszarze, nie można traktować jako pochówków, gdyż nie ma w nich kości ludzkich. Wynika z tego, że na cmentarzysku świelubskim nie mogą być obecne groby słowiańskich mieszkańców otwartych osad i grodu w Bardach. Nie ma też żadnej konieczności podejmowania na siłę (z różnych, jak można przypuszczać, powodów) prób uznania grobów ciałopalnych bez wyposażenia za słowiańskie, ponieważ ten typ pochówków pod kopcami występuje w epoce wikingów w środkowej Szwecji.

Jeżeli chodzi o przedmioty ze Ŝwielubia zidentyfikowane jako skandynawskie, to mogliśmy zapoznać się tu z ozdobami kobiecymi, częściami tarcz oraz ciężarkami wagowymi i pionkami do gier planszowych, czyli z artefaktami występującymi w grobach i osadach przede wszystkim w środkowej Szwecji, w Upplandzie. Kontekst szwedzkich znalezisk wskazuje jednoznacznie na elity społeczne bliskie władzy typu królewskiego.

Jeśli chodzi o chronologię badanych przedmiotów, to zaprezentowane wyniki studiów nad nimi wskazują na IX w., a szczególnie na jego 2 połowę.

Na koniec możemy zadać pytanie dotyczące powodów obecności w Świelubiu grupy Szwedów. Gdyby grupa ta była pochodzenia duńskiego, nie musielibyśmy zastanawiać się szczególnie długo, dlaczego znalazła się ona na Pomorzu. Wiemy, że kilka duńskich emporiów handlowo-rzemieślniczych istniało na wybrzeżu meklemburskim i przedpomorskim, tzn. na ziemiach Obodrytów i Wieletów, już od VIII w., znikając z mapy na przełomie IX i X stulecia. Działały w nich społeczności duńskie składające się z całych rodzin, z mężczyzn, kobiet i dzieci. Wolin u ujścia Odry był ośrodkiem słowiańskim, w którym Duńczycy odgrywali znaczną rolę dopiero od połowy wieku X i jak na razie nie ma tam śladów po skandynawskich kobietach, co jest tłumaczone specyfiką Wolina: mamy przebywających tam kupców, ale i wojowników związanych z działalnością duńskiego króla Haralda Sinozębego. Widząc tak duże zaangażowanie duńskie na słowiańskim wybrzeżu, rozumiemy jeszcze lepiej, dlaczego odpowiedź na powyżej postawione pytanie jest ważna. Więc raz jeszcze: dlaczego Szwedzi?

Zacznijmy od przypomnienia, gdzie żył lud Sweów (svear) w epoce wikingów.

Wczesna Szwecja to obszar wokół jeziora Mälaren, mający nazwę Svitjod, występujący w źródłach łacińskich jako Svecia, w staroangielskim jako Swéopéod, a od średniowiecza, już jako królestwo, Swerriki (Duczko 2009, s. 64 nn.; też Lindström, Lindström 2006).

Pierwotną i przez dłuższy czas główną jej częścią był obszar na północ od jeziora, zwany od średniowiecza Uppland. Znajdowało się tam najważniejsze miejsce kultowe w Uppsali (Starej) oraz tradycyjne nekropolie miejscowych elit w Valsgärde i Vendel (pierwsza miejscowość znajduje się około $5 \mathrm{~km}$ na północ od Starej Uppsali, a druga $15 \mathrm{~km}$ od niej). Svitjod jest najbogatszą pod względem odkrytych archeologicznie zabytków częścią Szwecji, gdyż obok licznych cmentarzysk przy gospodarstwach chłopskich mamy tam miejsca kultowe z dużymi ilościami ofiarowanych przedmiotów oraz miejsca władzy z bogato wyposażonymi grobami. Uppland jest dobrze zbadany archeologicznie i otrzymany obraz epoki wikingów manifestuje 


\section{CONCLUSIONS}

Having presented the graves and the artifacts found inside them, we can move to formulating some conclusions. To start with the Świelubie cemetery as a whole. Its poor state of preservation and low number of excavated graves precludes both a discussion of the timeframe for the Scandinavian group living on the banks of the lower Parsęta and a determination of the ethnicity of the deceased. Łosiński's efforts to determine other than Scandinavian origins for some of the deceased buried in this cemetery should not be accepted as fully correct, partly because of its $9^{\text {th }}$-c. chronology when Pomerania was still part of the Veleti cultural zone with a predominant graveless ritual (the frequent pits of the Alt Käbelich type in this region cannot be considered as burials because they never contained any human bones). It follows that there cannot be any burials of Slavs living in the unfortified villages and the stronghold at Bardy in the Swielubie cemetery nor is there any need to force the view (for a variety of reasons I should think) that the cremation burials without grave goods were actually Slavic, because this type of burial under a mound is common in central Sweden in the Viking Age.

With regard to the artifacts from Swielubie identified as Scandinavian, they include female ornaments, parts of shields, balance weights and game counters, that is, objects present in settlement and sepulchral contexts primarily in Uppland in central Sweden. The context of the Swedish finds point to a social elite close to royal circles.

The chronology of the examined artifacts was established in the $9^{\text {th }}$ c., especially its $2^{\text {nd }}$ half.

Finally, what was it that brought the group of Swedes to Swielubie? Had this group been of Danish origin, its presence in Pomerania would not have been considered as surprising. Several Danish trade and craft emporia dotted the Mecklenburg and Vorpommern coast, in the territories of the Obrodites and the Veleti, starting from the $8^{\text {th }} \mathrm{c}$. and disappearing at the close of the $9^{\text {th }} \mathrm{c}$. Danish communities comprised whole families, men, women and children. Wolin at the mouth of the Oder was a Slavic center and the Danes started to play an important role there after the mid-10 ${ }^{\text {th }} \mathrm{c}$. The absence of any evidence of Scandinavian women at Wolin is explained by the specificity of this center, which was visited by merchants, but also by warriors linked to the Danish King Harald "Bluetooth". Considering the extent of Danish involvement on the Slavic seashore, one wonders even more about the presence of the Swedes.

Let us first take a look at where the Svears were living during the Viking Age. Early Sweden is the region around lake Mälaren, which was called Svitjod and which appeared in Latin sources as Svecia, Swéopéod in old English and as Swerriki already as a kingdom (Duczko 2009, p. 64ff.; also Lindström, Lindström 2006). The core region and for a long time its main part was the area north of the lake, called Uppland in medieval times. The most important cult place in Old Uppsala was located there along with the traditional cemeteries of the local elites in nearby Valsgärde about $5 \mathrm{~km}$ north of Old Uppsala and the more distant Vendel $15 \mathrm{~km}$ 
wyraźnie swoją różnorodność i typowość. Znając materiał archeologiczny z tego obszaru, a także ten, który odkryto w Europie Wschodniej kolonizowanej od VIII w. przez ludność ze Svitjod, możemy z dużą pewnością dokonywać identyfikacji przedmiotów znajdowanych na innych terenach.

Po tej krótkiej prezentacji wróćmy do naszego pytania: dlaczego Szwedzi pojawili się w 2 poł. IX w. nad Parsętą? Wydaje mi się, że dalej możemy pracować z dwiema hipotezami. Przy pierwszej wychodzimy z założenia, że Szwedzi przybyli tu zza ujścia Wisły, z emporium Truso, które w IX w. miało nadal szwedzko-gotlandzki charakter. Druga jest bardziej skomplikowana i wiąże się z faktem przynależności Blekinge - obszaru we wschodniej Skandynawii, znajdującego się prawie w linii prostej naprzeciwko wybrzeża pomorskiego - do Szwedów. Dowiadujemy się o tym z relacji o wyprawie z Hedeby do Truso, w ostatnim dziesięcioleciu IX w., podróżnika Wulfstana, wchodzącej w skład Chorografii Orozjusza przetłumaczonej na dworze angielskiego króla Alfreda Wielkiego. Inne, późne relacje, przekazują nam informacje o zajęciu Hedeby przez Szwedów, którzy tam mieli swoje władztwo do końca lat trzydziestych X w. Zajęcie Blekinge było jednym z działań Szwedów podążających na południe w stronę rozpadającego się królestwa duńskiego. Z jakiegoś powodu grupa Szwedów na skutek spotkań z ludźmi z Pomorza uznała za opłacalne osiąść nad Parsętą, gdzie istniał silny ośrodek plemienny. Przybysze zostali tam na kilkadziesiąt lat.

Dalsze badania pokażą, jak mam nadzieję, czy którąś z tych hipotez da się w zadowalającym stopniu podbudować materiałem źródłowym.

\section{PO DRUGIEJ STRONIE RZEKI}

Kilka lat temu dr Katarzyna Skrzyńska z Instytutu Archeologii i Etnologii PAN w Warszawie pokazała mi zdjęcie terenu nad dolną Parsętą wykonane przy pomocy LiDAR-u (ryc. 10; 11). Ponieważ widziałem podobne zdjęcie z Birki byłem zaskoczony podobieństwami między tymi miejscami. Birka była o wiele większa, ale dwa wały, między którymi znajdowały się cmentarzyska kurhanowe, podkreślały podobieństwo. To zdjęcie przywiodło mnie z powrotem do Świelubia i doprowadziło do napisania obecnego artykułu.

Zapoznając się z publikacjami Władysława Łosińskiego poświęconymi grodowi w Bardach i cmentarzysku w Świelubiu, napotykamy wzmianki o stanowiskach archeologicznych - cmentarzyskach i osadach - obok wsi Skronie (nazwa została utworzona po roku $1945 \mathrm{z}$ niemieckiej Krühne) znajdującej się po lewej stronie rzeki Parsęty, około $2 \mathrm{~km}$ na południowy zachód od Bardów. W trakcie rozpoznania archeologicznego w końcu lat pięćdziesiątych XX w. W. Łosiński stwierdził tam obecność cmentarzyska kurhanowego podobnego do świelubskiego, osady, oraz dalej położonej koncentracji kopców w bliskości dwóch wałów ziemnych (Łosiński 1957; 1964; 1969).

Cmentarzysko, nazwane stanowiskiem 1, składa się ze 150 kopców, z których trzy zostały zbadane wykopaliskowo, nie dostarczając żadnych przedmiotów mogą- 
away. In terms of archaeological discoveries, Svitjod is the richest region in Sweden, comprising numerous cemeteries next to peasant homesteads, as well as cult places with large quantities of offerings and power centers with richly furnished graves. Uppland is investigated extensively, the results giving an extensive view of Viking culture in all its typicality and diversity. Knowing the archaeological material from this region and from the eastern regions of Europe, which were under colonization by people from Svitjod from the $8^{\text {th }} \mathrm{c}$. on, allows researchers to identify as Swedish with considerable certainty objects found in other territories.

In light of these facts, let us once again ask what were the Swedes doing on the banks of the Parsęta in the $2^{\text {nd }}$ half of the $9^{\text {th }} c$.? There are two possible hypotheses to consider. The first one assumes that the Swedes came here from the emporium in Truso beyond the mouth of the Vistula; in the $9^{\text {th }} \mathrm{c}$. it still had a Swedish-Gotlandic character. The second idea is more complicated and is connected to the fact that Blekinge, an area in eastern Scandinavia, situated directly opposite the Pomeranian shore, belonged to the Swedes. This information comes from a report of the traveler Wulfstan journeying from Hedeby to Truso in the last decade of the $9^{\text {th }}$ c.; the report is part of the Chorography by Orosius, translated at the court of the British king Alfred the Great. Other late reports tell of Hedeby being conquered by the Swedes, who ruled it until the end of the 930s. The Swedes occupied Blekinge on their way south, aiming at the declining kingdom of Denmark. For some reason a group of Swedes was persuaded by their contacts with the people from Pomerania to settle on the banks of the Parsęta where a strong tribal center existed. They stayed there for several dozen years.

Further research will show whether either one of these ideas will find satisfactory evidence to support it in the source material.

\section{ON THE OTHER SIDE OF THE RIVER}

A few years ago Dr. Katarzyna Skrzyńska from the Institute of Archaeology and Ethnology of the Polish Academy of Science in Warsaw showed me a LiDAR image of the terrain in the lower run of the Parsęta river (Figs 10; 11). I had seen similar images from Birka and was astounded by the similarities between the two places. Birka was much larger in size, but the two embankments with the barrow cemetery in between underscored the similarity. This image led me to revisit Świelubie and to write the present article.

In his publications of the stronghold in Bardy and cemetery in Świelubie, Władysław Łosiński mentioned archaeological sites, cemeteries and settlements, next to the village of Skronie (the name is a post-1945 invention from the German place name Krühne) on the left bank of the Parsęta river, about $2 \mathrm{~km}$ southwest of Bardy. During an archaeological reconnaissance of the area in the late 1950s, Łosiński recorded a barrow cemetery similar to the one at Świelubie, a settlement and a cluster of mounds at some distance, situated between two earth embankments (Łosiński 1957; 1964; 1969). 


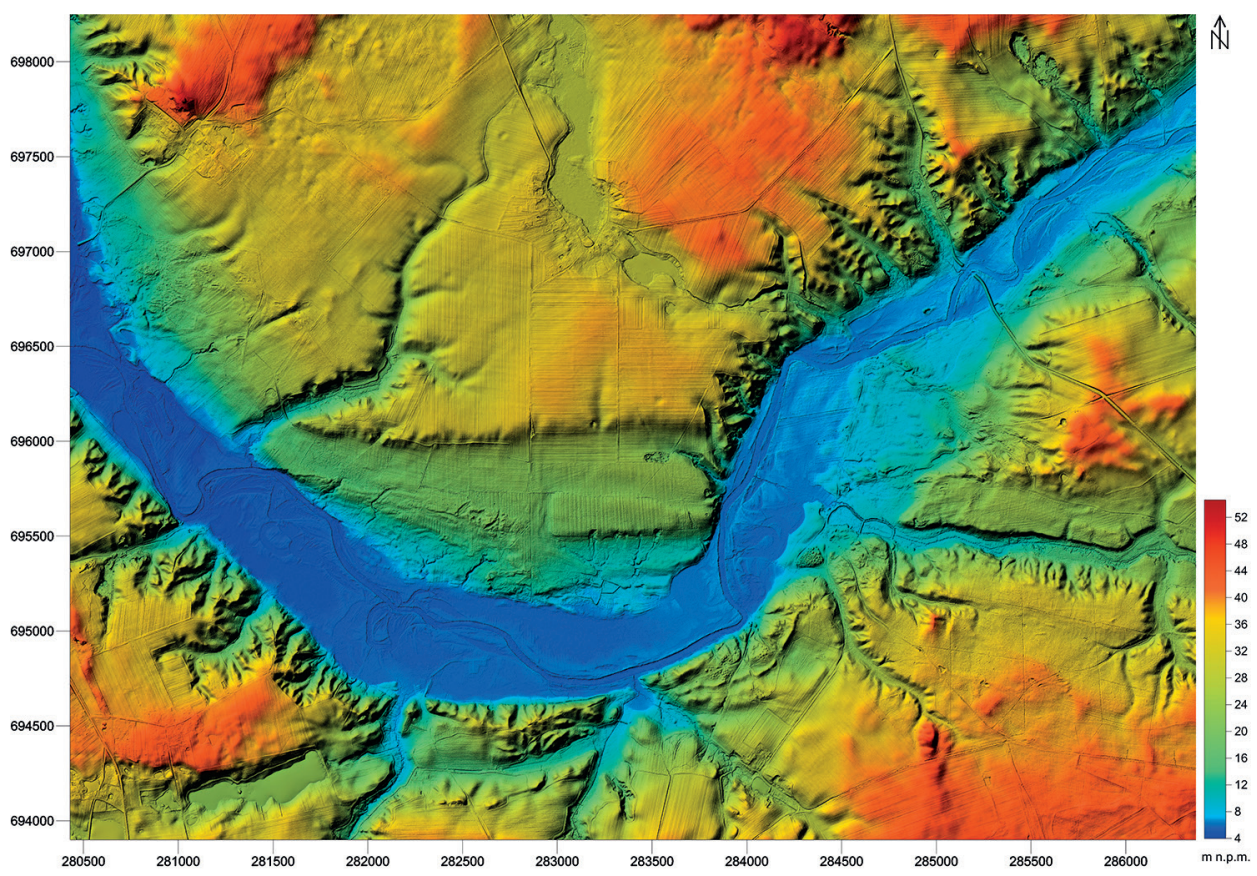

Ryc. 10. Pomorze, dolna Parsęta - Skronie powyżej koordynatów geograficznych 283500-284000.

Opracował W. Małkowski

Fig. 10. Pomerania, the lower run of the Parsęta river - Skronie above geographic coordinates 283500-284000 .

Processing W. Małkowski

cych określić przynależność kulturową pochowanych. Po tych badaniach kompleks zabytkowy w Skroniu przestał interesować archeologów. Skronie było od czasu do czasu wspominane w artykułach przez W. Łosińskiego. Omawiając gród w Bardach, stwierdził: „W VIII wieku mieszkańcy grodu być może chowali swoich zmarłych także na cmentarzysku w Skroniu" (Łosiński 1972, s. 259). Również Helena Zoll-Adamikowa robiła odnośniki do tej nekropolii (Zoll-Adamikowa 1980).

Według mojej wiedzy Skronie nie było jednak przedmiotem szczegółowej analizy, co powinno nas zastanowić. Trzeba więc zadać pytanie, dlaczego stanowiska, tak podobne do tych ze Świelubia, zostawiono same sobie. Możliwe, iż w grę wchodziła obawa, że pojawi się tam jeszcze więcej zabytków skandynawskich, co - pamiętając o kłopotach z czasów PRL, jakie wikińskie artefakty sprawiały archeologom - jest całkiem możliwe. A może było wręcz przeciwnie i to brak skandynawskich śladów na wstępnym etapie badań spłoszył uczonych albo zniechęciło ich podejrzenie, że stanowiska należały do kultury epoki brązu, choć akurat to w żaden sposób nie powinno być przeszkodą dla dalszych badań. Znajomość powodów, dla których poprzednicy nie przebadali Skronia, jest ważna, gdyż pozwoli uniknąć pójścia tą 


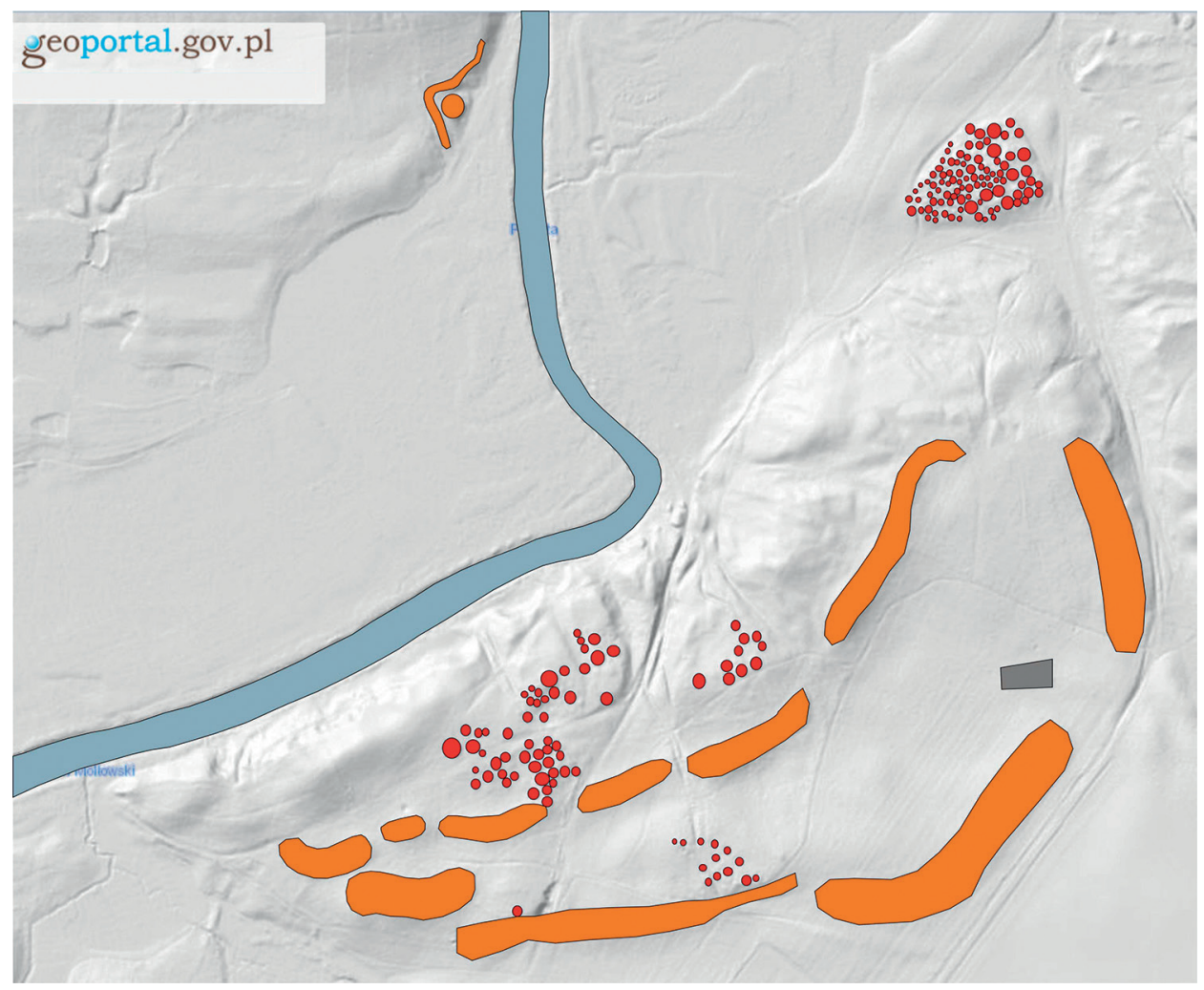

Ryc. 11. Pomorze, dolna Parsęta, kompleks archeologiczny Skronie.

Opracowała K. Skrzyńska

Fig. 11. Pomerania, the lower run of the Parsęta river, Skronie archaeological complex.

Processing K. Skrzyńska

The cemetery, designated as site 1 , counted 150 mounds, three of which were excavated, but without producing any finds that could determine the cultural attribution of these burials. Archaeologists ceased to take an interest in the site after that. Łosiński mentioned Skronie a couple of times in his later articles. Discussing the Bardy stronghold, he wrote: "In the $8^{\text {th }}$ century the inhabitants of the stronghold may have buried their dead also in the cemetery at Skronie" (Łosiński 1972, p. 259). Helena Zoll-Adamikowa also referred to the cemetery (Zoll-Adamikowa 1980).

To my knowledge, Skronie was never the object of a more detailed investigation, which makes one wonder why sites like Świelubie were left alone. Fear of finding more Scandinavian artifacts is a possibility considering the problems that archaeologists had with Viking heritage in Polish People's Republic. Perhaps the opposite is true and the very absence of Scandinavian traces was a deterrent for researchers; they may have suspected a Bronze Age affiliation of the sites, although this should hardly be a reason to avoid research. Work at the sites should be resumed and 
samą drogą, a wznowić prace trzeba. Warto bowiem nie tylko publikować materiały z wykopalisk w Bardach-Świelubiu, czcząc zmarłego przed kilku laty profesora Władysława Łosińskiego, ale też podjąć trud bliższego zbadania stanowisk już przez Niego wyznaczonych i wstępnie zbadanych ${ }^{1}$.

${ }^{1}$ Artykuł powstał w ramach grantu UMO-2016/22/M/H83/00210 Narodowego Centrum Nauki. 
understanding the reasons for the lack of interest could help to avoid earlier misconceptions. Not only should the material from the Bardy-Świelubie excavations be published in commemoration of the scholar Władysław Łosiński, who passed a few years back, but comprehensive research is also called for on sites that he discovered and had the opportunity to study in provisional manner. ${ }^{1}$

Translated by Iwona Zych

${ }^{1}$ Work on the article has been funded from National Science Centre grant UMO-2016/22/M/ $\mathrm{H} 83 / 00210$. 


\section{WYKAZ CYTOWANEJ LITERATURY}

\section{BIBLIOGRAPHY OF WORKS CITED}

A d a m c z y k D. 2018, Srebro i władza. Trybuty i handel dalekosiężny a kształtowanie się państwa piastowskiego i państw sąsiednich w latach 800-1100, transl. A. Gadzała, Warszawa.

A d a m c z y k P. 2011, Gry typu TAFL - próba klasyfikacji i propozycje zasady gry, „Elbląskie Studia Muzealne", 2, pp. 148-184.

A m brosiani B., E riks on B.G. 1996, Birka vikingastaden, 5: Vikingastaden lever upp igen i TV:s model av 800-talets Birka, Stockholm.

A n d e r s e n H.H. 1987, Vorchristliche Königsräber in Dänemark und ihre Hintergründe - Versuch einer Synthese, „Germania”, 65, pp. 159-173.

A n d e r s s o n G. 1997, Valsta gravfält. Arlandabanan. Arkeologisk undersökning. Rapport / UV Stockholm, 9/1, Stockholm.

A n d r o s h chu k F. 2007, The Rural Vikings and the Viking Helgö, [in:] Cultural interaction between east and west. Archaeology, artefacts and human contacts in northern Europe, U. Fransson, M. Svedin, S. Bergerbrant, F. Androshchuk eds, Stockholm Studies in Archaeology, 44, Stockholm, pp. 153-163.

A r b m a n H. 1937, Schweden und das karolingische Reich. Studien zu den Handelsverbindungen des 9. Jahrhunderts, Kungl. Vitterhets, Historie och Antikvitets Akademiens Handlingar, 43, Stockholm.

A r b m a n H. 1940, Die Gräber: Tafeln, Birka, 1, Stockholm.

A r b m a n H. 1943, Die Gräber: Text, Birka, 1, Stockholm.

A r r h e n i u s B. 1990, Utgrävningen av den östligaste storhögen på gravfältet Ormknös. RAÄ 111, Björkö, Adelsö sn, Uppland, „Laborativ arkeologi”, 4, pp. 65-80.

Arrhenius B., Holmqvist L., Was e K. 1978, Arkeologiska undersökningar vid Ormknös, Björkö, Adelsö sn, Uppland: rapport, Rapport från Stockholms universitets arkeologiska forskningslaboratorium, 1, Stockholm.

A r w i d s s o n G. 1984, Glas, [in:] Systematische Analysen der Gräberfunde, Birka. Untersuchungen und Studien, II/1, G. Arwidsson ed., Stockholm, pp. 203-212.

A r w i d s s o n G. 1986, Schilde, [in:] Systematische Analysen der Gräberfunde, Birka. Untersuchungen und Studien, II/2, G. Arwidsson ed., Stockholm, pp. 38-44.

B a n a z ki e w i c z J. 2018, Rodulf, król Herulów, który grat (Paweł Diakon, Hist. Long., I, 20), [in:] J. Banaszkiewicz, W stronę rytuałów i Galla Anonima, Kraków, pp. 264-275.

B j a r n a s o n B. [1911-1913] 1913, Brettspiel, [in:] Reallexikon der Germanischen Altertumskunde, 1: A-E, J. Hoops ed., Strassburg, pp. 311-314.

B r u n s t e d t S. 1996, Alsnu Kungsgård. Forskningsprojekt Hovgården, Uppland, Adelsö socken, RÄ̈ 46 m fl, Dr 764-91, arkeologisk undersökning, Rapport / UV Stockholm, 71/1, Stockholm.

C a p elle T. 1968, Kleeblattfibeln und Zierketten, „Fornvännen”, 63, pp. 1-9.

D u c z k o W. 1985, The filigree and granulation work of the Viking period. An analysis of the material from Björkö, Birka, Untersuchungen und Studien, V, Stockholm.

D u c z k o W. 1995, Kungar, thegnar, Tegnebyar, juveler och silverskatter. Om danskt inflytande $i$ Sverige under senvikingatid, Sum.: Kings, thengs, Tegnebys, jewellery and hoards. On Danish influence in Sweden during the late Viking Age, „Tor”, 27/2, pp. 625-662.

D uczko W. 1997, Gamla Uppsala, [in:] Reallexikon der Germanischen Altertumskunde, 10/L.5/6, Berlin-New York, pp. 409-418. 
D u c zko W. 2000, Obecność skandynawska na Pomorzu i słowiańska w Skandynawii we wczesnym średniowieczu, Sum.: Skandinavische Präsenz in Pommern und die slawische in Skandinavien im frühen Mittelalter, [in:] Salsa Cholbergiensis. Kołobrzeg w średniowieczu, L. Leciejewicz, M. Rębkowski eds, Kołobrzeg, pp. 23-44.

D u c z k o W. 2002, Test or Magic? Pecks on Viking-Age Silver, [in:] Moneta mediaevalis. Studia numizmatyczne i historyczne ofiarowane Profesorowi Stanisławowi Suchodolskiemu w 65. rocznice urodzin, R. Kiersnowski ed., Warszawa, pp. 192-208.

D u c z k o W. 2004, Viking Rus. Studies on the Presence of Scandinavians in Eastern Europe, Brill, Leiden-Boston.

D u c z k o W. 2005, Zebrać, zdeprecjonować, schować i zapomnieć. O skarbach srebrnych Skandynawii okresu wikingów, Sum.: To collect, depreciate, hide and forget. About hoards of silver in the Viking Age Scandinavia, „Wiadomości Numizmatyczne”, 49/2 (180), pp. 205-218.

D u c z k o W. 2006, Ruś Wikingów. Historia obecności Skandynawów we wczesnośredniowiecznej Europie Wschodniej, tłum. N. Kreczmar, Warszawa.

D u c z k o W. 2009, Danes and Swedes in written and archaeological sources at the end of the $9^{\text {th }}$ century, [in:] Wulfstan's voyage. The Baltic Sea region in the early Viking Age as seen from shipboard, A. Englert, A. Trakadas eds, Maritime Culture of the North, 2, Roskilde, pp. 58-71.

D u c z k o W. 2011, Wikingowie i wczesnośredniowieczna Polska, [in:] Swoi i obcy w kulturze średniowiecza. Wykłady popularno-naukowe zorganizowane $w$ ramach VII Festiwalu Kultury Słowiańskiej i Cysterskiej w Ladzie nad Warta w dniach 18-19 czerwca 2011, M. Brzostowicz, M. Przybył, J. Wrzesiński eds, Poznań-Ląd, pp. 61-69.

D u c z k o W. 2014, Viking-Age Wolin (Wollin) in the Norse context of the southern coast of the Baltic Sea, „Scripta Islandica”, 65, pp. 143-151.

D u c z k o W. 2016a, Moce wikingów, 1: Światy i zaświaty wczesnośredniowiecznych Skandynawów, Warszawa.

D u c z ko W. 2016b, Skandynawowie na Mazowszu, [in:] Swoi i obcy na Mazowszu Pótnocnym w minionym tysiącleciu, A. Koseski, R. Lolo, J. Szczepański eds, Pułtusk, pp. 237-242.

D u c z k o W. 2016c, Status i magia. Ozdoby elit pochowanych w Bodzi, [in:] Bodzia. Elitarny cmentarz z początków państwa polskiego, A. Buko ed., Warszawa, pp. 115-135.

D u c z k o W. 2016d, Złoty młot boga Thora? O fragmencie skandynawskiej ozdoby z Ostrowa Lednickiego, [in:] Ostrów Lednicki. Rezydencjonalno-stołeczny ośrodek pierwszych Piastów, Z. Kurnatowska, A.M. Wyrwa eds, Origines Polonorum, 9, P. Urbańczyk ed., Warszawa, pp. 298-301.

D u c z k o W. 2017, Skandynawowie w Europie Wschodniej i na ziemiach polskich we wczesnym średniowieczu. Recepcja i odrzucenie - kiedyś i dzisiaj, [in:] Recepcja i odrzucenie. Kontakty międzykulturowe w średniowieczu, L.P. Słupecki, P. Sierżęa, A. Rozwałka, M. Dzik eds, Materiały V Kongresu Mediewistów Polskich, 1, Rzeszów, pp. 67-81.

D ulinicz M. 2001, Kształtowanie się Słowiańszczyzny Północno-Zachodniej. Studium archeologiczne, Zusamm.: Die Herausbildung der Nordwestslawen. Archäologische Studien, Warszawa.

E g g e r s H.J. 1938, Das Wikingergrab von Zwilipp, Kr. Kolberg-Körlin, „Monatsblätter der Gesellschaft für Pommersche Geschichte und Altertumskunde”, 52/1, pp. 7-9.

Häg g I. 1983, Birkas orientaliska praktplagg, Zusamm.: Birkas "orientalische" Prunkgewänder, „Fornvännen”, 78, pp. 204-223.

Hall M.A. 2016, Board games in boat burials: play in the performance of migration and Viking age mortuary practice, „European Journal of Archaeology”, 19/3, pp. 439-455. 
Hår d h B . 1984a, Feuerstahl, [in:] Systematische Analysen der Gräberfunde, Birka. Untersuchungen und Studien, II/1, G. Arwidsson ed., Stockholm, pp. 155-160.

H å r d h B . 1984b, Kleeblattfibeln, [in:] Systematische Analysen der Gräberfunde, Birka. Untersuchungen und Studien, II/1, G. Arwidsson ed., Stockholm, pp. 85-94.

H e d e n s t i e r n a - J o n s o n C. 2001, Befästa handelsstäder, garnisoner och professionella krigare, [in:] Birkas krigare. 11 artiklar kring Birkas befästningsverk och dess krigare, M. Olausson ed., Borgar och befästningsverk i Mellansverige 400-1100 e. Kr., 5, Stockholm, pp. 65-72.

Holm q i st Ol a u s on L. 1993, Aspects on Birka. Investigations and surveys 1976-1989, Theses and Papers in archaeology, B/3, Stockholm.

Ja g o dzińs ki M. F. 2010, Truso. Między Weonodlandem a Witlandem/Between Weonodland and Witland, Elbląg.

Ja g o d zi ń ski M. F. 2015, Truso - legenda Bałtyku. Katalog wystawy, $2^{\text {nd }}$ edition, Elbląg.

Ja n s s o n I. 1985, Ovala spännbucklor. En studie av vikingatida standardsmycken med. utgångspunkt från Björkö-fynden / Oval brooches. A study of Viking Period standard jewellery based on the finds from Björkö (Birka), Sweden, Archaeological studies / Uppsala University, Institute of North European Archaeology, 7, Uppsala.

Jö n s H. 2009, Ports and emporia of the southern coast: from Hedeby to Usedom and Wolin, [in:] Wulfstan's voyage. The Baltic Sea region in the early Viking age as seen from shipboard, A. Englert, A. Trakadas eds, Maritime Culture of the North, 2, Roskilde, pp. 160-181.

K l e i n gä r t n e r S. 2014, Die frühe Phase der Urbanisierung an der südlichen Ostseeküste im ersten nachchristlichen Jahrtausend, Studien zur Siedlungsgeschichte und Archäologie der Ostseegebiete, 13, Neumünster.

Ky h l b e r g O. 1973, Viktlod, [in:] Birka. Svarta jordens hamnområde. Arkeologisk undersökning 1970-1971, Rapport / Riksantikvarieämbetet, C/1, pp. 207-215.

L a r s s o n A. 2007, Klädd krigare. Skifte i skandinaviskt dräktskick kring år 1000, Analytic discussion and summary, Occasional papers in archaeology, 39, Uppsala.

L e c i e j e w i c z L. 1993, Normanowie nad Odra $i$ Wisła w IX-XI wieku, „Kwartalnik Historyczny", 100/4, pp. 49-62.

L e n n a r t s s o n M. [1997/1998] 1999, Karolingische Metallarbeiten mit Pflanzenornamentik, „Offa”, 54/55, pp. 431-619.

L in d st rö m H., L i n d st r ö m F. 2006, Svitjods undergång och Sveriges födelse, Stockholm.

L u n d s trö m A. e d. 1988, Thirteen Studies on Helgö, Studies / The Museum of National Antiquities, Stockholm, 7, Stockholm.

L u n d s t rö m P. 1981, De kommo vida ... Vikingars hamn vid Paviken på Gotland, Sjöhistoriska museets rapportserie, 15 , Stockholm.

Ło s iń s k i W. 1957, Badania powierzchniowe w dorzeczu Regi i Parsęty, „Materiały Zachodnio-Pomorskie", 3, pp. 175-188.

Ło s iński W. 1964, Sprawozdanie z badań archeologicznych Ekspedycji Wykopaliskowej IHKM PAN w Świelubiu i Bardach, pow. Kołobrzeg w 1962 roku, „Sprawozdania Archeologiczne", 16, pp. 153-168.

Łos iński W. 1966, Badania archeologiczne w Świelubiu i Bardach, pow. Kołobrzeg, w 1964 roku, Sum.: Archaeological investigations at Bardy and Swielubie, Distr. Kołobrzeg in 1964, „Sprawozdania Archeologiczne”, 18, pp. 161-172.

Ło s i ń s k i W. 1968, Badania archeologiczne w Bardach i Świelubiu, pow. Kołobrzeg, w 1965 r. Sum.: Excavations at Bardy and Świelubie, Distr. Kołobrzeg in 1965, „Sprawozdania Archeologiczne", 19, pp. 144-157. 
Ł o s i ń s k i W. 1969, Dalsze badania archeologiczne w Świelubiu, pow. Kołobrzeg, „Sprawozdania Archeologiczne", 21, pp. 153-162.

Ł o s iń s k i W. 1972, Początki wczesnośredniowiecznego osadnictwa grodowego $w$ dorzeczu dolnej Parsęty (VII-X/XI w.), Wrocław.

Ł o s ińs ki W. 1973, Wczesnośredniowieczny zespół osadniczy w Bardach i Świelubiu pod Kołobrzegiem, „Koszalińskie Zeszyty Muzealne”, pp. 102-119.

Ł o s i ń s k i W. 1974, Srebrny wystrój odzieży z wczesnośredniowiecznego cmentarzyska w Świelubiu w powiecie kołobrzeskim, [in:] Studia archaeologica Pomeranica, F.J. Lachowicz ed., Koszalin, pp. 159-175.

Ł o s i ń s k i W. 1979, Die Kontakte zwischen Pommern und Skandinavien im frühen Mittelalter im Lichte von Forschunge im unteren Parsęta-Flußgebiet, [in:] Rapports du IIIe Congrès International d’Archéologie Slave, Bratislava 7-14 septembre 1975, B. Chropovský ed. 1, Bratislava, pp. 513-518.

Ł o s i ń s k i W. 1993, Groby typu Alt Käbelich w świetle badań przeprowadzonych na cmentarzysku wczesnośredniowiecznym w Świelubiu pod Kołobrzegiem, Zusamm.: Gräber vom Typ Käbelich im Lichte der Ausgrabungen auf dem frühmittelalterlichen Gräberfeld in Świelubie bei Kołobrzeg, „Przegląd Archeologiczny”, 41, pp. 17-34.

Ło s iński W. 1998, Z dziejów obrzędowości pogrzebowej u pótnocnego odłamu Słowian zachodnich w świetle nowszych badań, [in:] Kraje słowiańskie w wiekach średnich. Profanum i sacrum, H. Kóčka-Krenz, W. Łosiński eds, Poznań, pp. 473-483.

Ł o s i ń s k i W. 2000, Z badań nad obrządkiem pogrzebowym na słowiańskich wybrzeżach Battyku w dobie plemiennej - uwag ciag dalszy, „Archaeologia Historica Polona”, 8, pp. 71-81.

Ł o s i ń s k i W. 2003, Trójramienna zapinka skandynawska $z$ cmentarzyska $w$ Świelubiu pod Kołobrzegiem - aspekt chronologiczny, [in:] Słowianie i ich sąsiedzi we wczesnym średniowieczu, M. Dulinicz ed., Lublin-Warszawa, pp. 133-139.

Ł o s i ń s k i W. 2008, Pomorze Zachodnie we wczesnym średniowieczu. Studia archeologiczne, Zusamm.: Westpommern im Frühmittelalter. Archäologische Studien, Collectio Archaeologica, Historica et Ethnologica, 3, Poznań.

Ł o w m i á s k i H. 1957, Zagadnienie roli Normanów w genezie państw słowiańskich, Warszawa.

Mülle r-Wille M. 1976, Das Bootkammergrab von Haithabu, Berichte über die Ausgrabungen in Haithabu, 8, Neumünster.

Murray J.R.H. 1952, A history of board-games other than chess, Oxford.

Nils s o n C. 1972, Arkeologisk undersökning 1966: fornlämning 277, Turebergs Gård, Sollentuna sn, Uppland, Rapport / Riksantikvarieämbetet, B/1, Stockholm.

Nord m a n C.A. 1924, Karelska järnåldersstudier, „Suomen Muinaismuistoyhdistyksen aikakauskirja” / „Finska Fornminnesföreningens tidskrift”, 34/3.

Nylén E., S chönbäck B. 1994a, Tuna i Badelunda. Guld, kvinnor, båtar, 1, Sum.: Tuna in Badelunda. Gold, Women, Boats, Västerås Kulturnämnds skriftserie, 27; Västerås.

Nylén E., S chön bä ck B. 1994b, Tuna i Badelunda. Guld, kvinnor, båtar, 2, Västerås Kulturnämnds skriftserie, 30, Västerås.

Ols e n O. 1966, Hørg, hov og kirke. Historiske og arkøologiske vikingetidsstudier, København.

Ols e n V.S. [2005/2006] 2006, The development of (proto)-disc-on-bow brooches in England, Frisia and Scandinavia, „Palaeohistoria”, 47/48, pp. 479-428.

Peets J., A $11 \mathrm{mäe}$ R., Mald re L. 2010, Archaeological investigations of Pre-Viking Age burial boat in Salme village at Saaremaa, „Arheoloogilised Välitööd Eestis” / „Archaeological Fieldwork in Estonia", pp. 29-48. 
P e t e r s e n J. 1914, Bretspillet i Norge i forhistorisk tid, „Oldtiden”, 4, pp. 75-92.

P e t e r s e n J. 1919, De norske vikingesverd. En typologisk-kronologisk studie over vikingetidens vaaben, Skrifter / Videnskabsselskapet i Kristiania, II, Historisk-filosofisk Klasse, 1, Kristiania.

Pet e r s e n J. 1928, Vikingetidens smykker, Stavanger.

Rudzińs ki P. M. 2009, Tarcza we wczesnośredniowiecznej Polsce na tle europejskim: od plemienia do państwa, „Acta Militaria Mediaevalia”, 5, pp. 21-78.

Ryd h H. 1936, Förhistoriska undersökningar på Adelsö, Deutscher Auszug, Monografier / Kungl. Vitterhets-, historie- och antikvitetsakademien, 24, Stockholm.

Słu p e cki L.P. 2000, Jómsvikingalog, Jómsvikings, Jomsborg/Wolin and Danish circular strongholds, [in:] The neighbours of Poland in the $10^{\text {th }}$ century, P. Urbańczyk ed., Warszawa, pp. 49-59.

S perber E. 1996, Balances, weights and weighing in ancient and early medieval Sweden, Theses and papers in scientific archaeology, 2, Stockholm.

S t a n i sła w ski B. M. 2013, Jómswikingowie z Wolina-Jómsborga-studium archeologiczne przenikania kultury skandynawskiej na ziemie polskie, Sum.: Jómsvikings from Wolin-Jómsborg - the diffusion of Scandinavian culture on the Polish territory. An archaeological study, Wrocław.

S t e n b e r g e r M. [1961] 1962, Das Gräberfeld bei Ihre im Kirchspiel Hellvi auf Gotland. Der wikingerzeitliche Abschnitt, „Acta Archaeologica”, 32, pp. 1-134.

S t e u e r H. 2012, Waagen und Gewichte in Janów. Wagi i odważniki wagowe z Janowa VI, [in:] S. Brather, M. F. Jagodziński, Der wikingerzeitliche Seehandelsplatz von Janów (Truso). Geophysikalische, archäopedologische und archäologische Untersuchungen 2004-2008 / Nadmorska osada handlowa z okresu Wikingów z Janowa (Truso). Badania geofizyczne, archeo-pedologiczne i archeologiczne w latach 2004-2008, Zeitschrift für Archäologie des Mittelalters, 24, Bonn, pp. 185-280.

S t j e r n a N .2001, Birkas krigare och deras utrustning, [in:] Birkas krigare. 11 artiklar kring Birkas befästningsverk och dess krigare, M. Olausson ed., Borgar och befästningsverk i Mellansverige 400-1100 e. Kr., 5, Stockholm, pp. 39-45.

Thu n m a rk-Nylén L. 1998, Die Wikingerzeit Gotlands, 2: Typentafeln, Stockholm.

Thu n m a r k- Nylé n L. 2006a, Bügelscheibenfiebln, [in:] L. Thunmark-Nylén, Die Wikingerzeit Gotlands, 3/1: Text, Stockholm, pp. 51-63.

Thunmark-Nylén L. 2006b, Schilde, [in:] L. Thunmark-Nylén, Die Wikingerzeit Gotlands, 3/1: Text, Stockholm, pp. 318-319.

W a m e r s E. 1994, König im Grenzland. Neue Analyse des Bootkammergrabes von Haiðaby, „Acta Archaeologica”, 65, pp. 1-56.

W i e r z b i cki A. 2011, Obcy w dziejach Polski. Hipoteza państwowotwórczego podboju w polskiej myśli historycznej XIX i początków XX wieku, „KLIO POLSKA. Studia i Materiały z Dziejów Historiografii Polskiej XIX i XX wieku”, 5, pp. 119-149.

W i e r z b i cki A. 2016, Między endo- a egzogeneza państwa polskiego. Polemiki historyków polskich $z$ historiografia niemiecka w czasach II Rzeczpospolitej, „KLIO POLSKA. Studia i Materiały z Dziejów Historiografii Polskiej”, 8, pp. 49-62.

Wi e r zbicki A. 2019, Jak powstało państwo polskie? Hipoteza podboju w historiografii polskiej XIX i XX wieku, Warszawa.

Z oll-A d a m i k o w a H. 1980, Einheimische und fremde Elemente im Grabkult der Ostseeslawen, „Offa”, 37, pp. 184-196.

Ż a k J. 1963, „Importy” skandynawskie na ziemiach zachodniosłowiańskich od IX do XI wieku (część katalogowa), Zusamm.: Skandinavische „Importe” in den westslawischen Ländern 
aus dem IX-XI Jahrhundert, Prace Komisji Archeologicznej / PTPN. Wydział Historii i Nauk Społecznych, 6/1, Poznań.

Ż a k J. 1967a, „Importy” skandynawskie na ziemiach zachodniosłowiańskich od IX do XI wieku (część analityczna), Zusamm.: Skandinavische „Importe” in den westslawischen Ländern aus dem IX-XI Jahrhundert. Analitischer Teil, Prace Komisji Archeologicznej / PTPN. Wydział Historii i Nauk Społecznych, 7/1, Poznań.

Ż a k J. 1967b, „Importy” skandynawskie na ziemiach zachodniosłowiańskich od IX do XI wieku (część syntetyczna), Zusamm.: Skandinavische „Importe” in den westslawischen Ländern aus dem IX-XI Jahrhundert. Synthetischer Teil, Prace Komisji Archeologicznej / PTPN. Wydział Historii i Nauk Społecznych, 7/2, Poznań. 